Review Article

\title{
Combating Pathogenic Microorganisms Using Plant-Derived Antimicrobials: A Minireview of the Mechanistic Basis
}

\author{
Abhinav Upadhyay, Indu Upadhyaya, \\ Anup Kollanoor-Johny, and Kumar Venkitanarayanan \\ Department of Animal Science, University of Connecticut, 3636 Horsebarn Hill Road Extension, Unit 4040, Storrs, CT 06269, USA \\ Correspondence should be addressed to Kumar Venkitanarayanan; kumar.venkitanarayanan@uconn.edu
}

Received 25 April 2014; Revised 5 August 2014; Accepted 8 August 2014; Published 14 September 2014

Academic Editor: Vasilis P. Valdramidis

Copyright (C) 2014 Abhinav Upadhyay et al. This is an open access article distributed under the Creative Commons Attribution License, which permits unrestricted use, distribution, and reproduction in any medium, provided the original work is properly cited.

\begin{abstract}
The emergence of antibiotic resistance in pathogenic bacteria has led to renewed interest in exploring the potential of plantderived antimicrobials (PDAs) as an alternative therapeutic strategy to combat microbial infections. Historically, plant extracts have been used as a safe, effective, and natural remedy for ailments and diseases in traditional medicine. Extensive research in the last two decades has identified a plethora of PDAs with a wide spectrum of activity against a variety of fungal and bacterial pathogens causing infections in humans and animals. Active components of many plant extracts have been characterized and are commercially available; however, research delineating the mechanistic basis of their antimicrobial action is scanty. This review highlights the potential of various plant-derived compounds to control pathogenic bacteria, especially the diverse effects exerted by plant compounds on various virulence factors that are critical for pathogenicity inside the host. In addition, the potential effect of PDAs on gut microbiota is discussed.
\end{abstract}

\section{Introduction}

Human population growth with its global effects on the environment over the past million years has resulted in the emergence of infectious diseases $[1,2]$. Development of agriculture further contributed to this, since these infections could only be sustained in large and dense human populations [3]. The discovery of antibiotics during the twentieth century coupled with significant advances in antimicrobial drug development improved human health through improved treatment of infections $[4,5]$. However, prolonged use of antibiotics led to bacterial adaptation, resulting in the development of multidrug resistance in bacteria $[2,5-8]$. This has significantly limited the efficacy of antibiotics, warranting alternative strategies to combat microbial infections.

The persistence of bacteria in the environment and their interaction with humans is central to most infections and illnesses. Bacterial illnesses are orchestrated by means of an array of virulence factors that facilitate various aspects of their pathophysiology critical for disease in the host [9]. These include adhesins and membrane proteins that mediate bacterial attachment, colonization, and invasion of host cells. In addition, microbial toxins cause host tissue damage, and bacterial cell wall components such as capsular polysaccharide confer resistance against host immune system $[10,11]$. Biofilm formation and spore forming capacity are additional virulence factors that help in the persistence of pathogens in harsh environmental conditions.

Since ancient times, plants have played a critical role in the development and well-being of human civilization. A plethora of plant products have been used as food preservatives, flavor enhancers, and dietary supplements to prevent food spoilage and maintain human health. In addition, plant extracts have been widely used in herbal medicine, both prophylactically and therapeutically for controlling diseases. The antimicrobial activity of several plant-derived compounds has been previously reported [12-23], and a wide array of active components have been identified [24]. A majority of these compounds are secondary metabolites and are produced as a result of reciprocal interactions between plants, microbes, and animals [25]. These compounds do not appear to play a direct role in plant physiology [26]; however they are critical for enhancing plant fitness and defense against predation [27]. The production of secondary 
metabolites is often restricted to a limited set of species within a phylogenetic group as compared to primary metabolites (amino acids, polysaccharides, proteins, and lipids), which are widespread in the plant kingdom [28]. Also, they are generated only during a specific developmental period of plant growth at micro- to submicromolar concentration [28, 29].

The primary advantage of using plant-derived antimicrobials (PDAs) for therapeutic purposes is that they do not exhibit the side effects often associated with use of synthetic chemicals [30]. In addition, to the best of our knowledge, no reports of antimicrobial resistance to these phytochemicals have been documented, probably due to their multiple mechanisms of action which potentially prevent the selection of resistant strains of bacteria. The marked antimicrobial effect, nontoxic nature, and affordability of these compounds have formed the basis for their wide use as growth promoters in the livestock and poultry industry, effective antimicrobials and disinfectants in the food industry, components of herbal therapy in veterinary medicine, and source for development of novel antibiotics in pharmaceutics.

The antimicrobial properties of various plant compounds that target cellular viability of bacteria have been adequately discussed previously $[12,31-33]$, but very few reviews have highlighted the effects of these compounds in modulating various aspects of bacterial virulence, critical for pathogenesis in the host. In this review, we have focused on a wide array of PDAs, with special emphasis on the diverse biological effects exerted by these compounds on bacterial virulence. The important classes of plant compounds and selected antimicrobial mechanisms have been discussed.

\section{Plant-Derived Antimicrobials}

Most plant-derived compounds are produced as secondary metabolites and can be classified based on their chemical structure, which also influences their antimicrobial property (Table 1). The major groups of phytochemicals are presented here.

2.1. Phenolics and Polyphenols. These are a diverse group of aromatic secondary metabolites involved in plant defense. They consist of flavonoids, quinones, tannins, and coumarins [33-35].

2.1.1. Flavonoids. Flavonoids are pigmented compounds found in fruits and flowers of plants and mainly consist of flavone, flavanones, flavanols, and anthocyanidins [34, 35]. They facilitate pollination by acting as chemoattractants for insects, modulate plant physiology by signaling to beneficial microbiota in rhizosphere, and protect plants against predation due to their antimicrobial nature [36]. The marked antimicrobial property of flavonoids against a variety of bacterial [37-39] and fungal pathogens [40] is mediated by their action on the microbial cell membranes [41]. They interact with membrane proteins present on bacterial cell wall leading to increased membrane permeability and disruption. Catechins belonging to this group exhibit inhibitory activity against both Gram-positive and Gram-negative organisms [42].

2.1.2. Quinones. Quinones are organic compounds consisting of aromatic rings with two ketone substitutions. Quinones are known to complex irreversibly with nucleophilic amino acids in protein, often leading to their inactivation and loss of function [43]. The major targets in the microbial cell include surface-exposed adhesin proteins, cell wall polypeptides, and membrane-bound enzymes [44]. Quinone such as anthraquinone from Cassia italica was found to be bacteriostatic against pathogenic bacteria such as Bacillus anthracis, Corynebacterium pseudodiphthericum, and Pseudomonas aeruginosa and bactericidal against Burkholderia pseudomallei [45].

2.1.3. Tannins. Tannins are a group of water-soluble oligomeric and polymeric polyphenolic compounds, with significant astringent properties. They are present in the majority of plant parts, including bark, leave, fruits, and roots [46]. They are widely used in leather industry, in food industry, and, as antimicrobials, in healthcare industry [47]. The mode of antimicrobial action of tannins is potentially due to inactivation of microbial adhesins and cell envelope transport proteins [47-49]. Besides their efficacy against bacteria, tannins have been reported to be inhibitory on fungi and yeasts $[46,50]$.

2.1.4. Coumarins. Coumarins are a group of aromatic benzopyrones consisting of fused benzene and alpha pyrone rings [51]. Approximately, 1300 coumarins have been identified since 1996 [44] and are used as antithrombotic and antiinflammatory compounds [52]. Recently, coumarins such as scopoletin and chalcones have been isolated as antitubercular constituents of the plant Fatoua pilosa [53]. In addition, phytoalexins, which are hydroxylated derivatives of coumarins, which are produced in plants in response to microbial infections, have been found to exert marked antifungal activity.

2.2. Alkaloids. Alkaloids are a group of heterocyclic nitrogenous compounds with broad antimicrobial activity. Morphine and codeine are the oldest known compounds in this group [54]. Diterpenoid alkaloids, commonly isolated from Ranunculaceae or buttercup family of plants, are found to possess antimicrobial properties [55]. The mechanism of action of aromatic planar quaternary alkaloids such as berberine and harmane is attributed to their ability to intercalate with DNA thereby resulting in impaired cell division and cell death [33].

2.3. Terpenoids. Terpenes represent one of the largest and most diverse groups of secondary metabolites consisting of five carbon isoprene structural units linked in various configurations [43]. The action of terpene cyclase enzymes along with subsequent oxidation and structural rearrangement imparts a rich diversity to the group with over 55,000 members isolated so far [56]. The major groups 


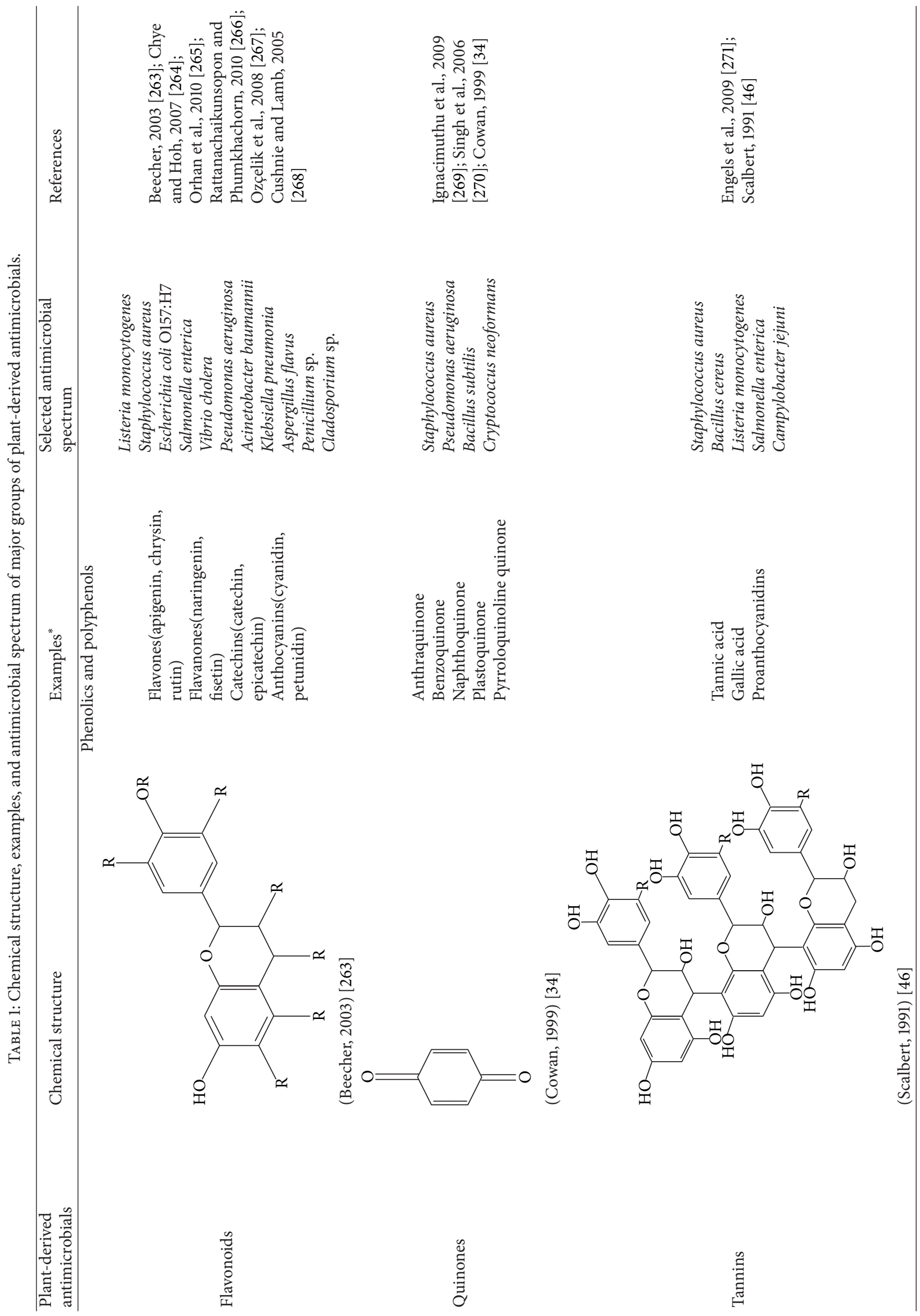




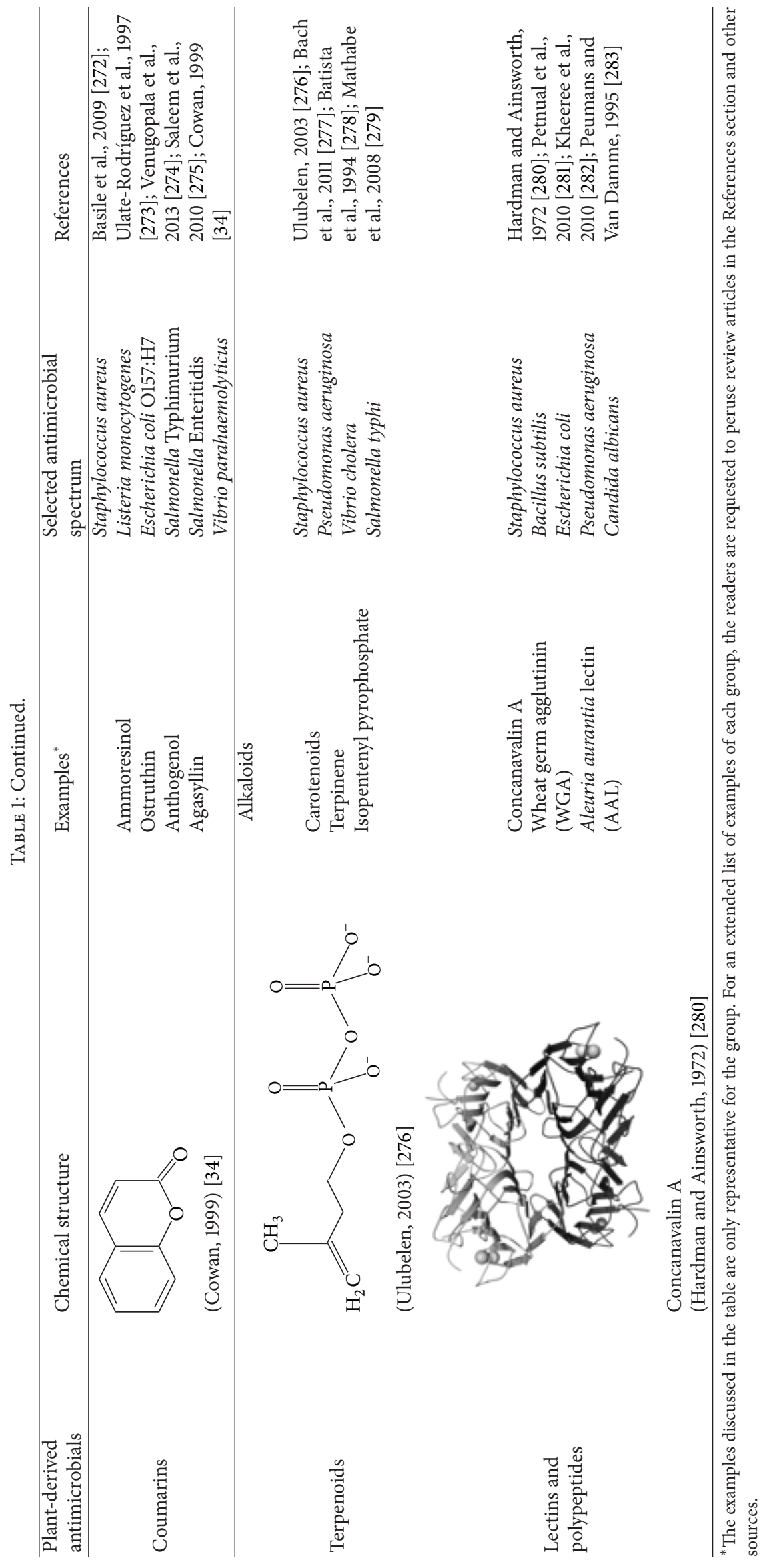


consist of diterpenes, triterpenes, tetraterpenes as well as hemiterpenes, and sesquiterpenes [44]. When the compounds contain additional elements, frequently oxygen, they are termed terpenoids. Compounds such as menthol and camphor (monoterpenes), farnesol and artemisinin (sesquiterpenoids) are terpenoids synthesized from acetate units and share their origins and chemical properties with fatty acids [34]. Sesquiterpenoids are known to exhibit bactericidal activity against Gram-positive bacteria, including M. tuberculosis $[35,53]$. The mechanism of antimicrobial action of terpenoids is not clearly defined, but it is attributed to membrane disruption in microorganisms [57].

2.4. Lectins and Polypeptides. In 1942, it was first reported that peptides could be inhibitory on microorganisms [58]. Although recent interest has chiefly focused on studying anti-HIV peptides and lectins, the inhibition of bacteria and fungi by these molecules has long been known [59]. The mechanism of action of peptides and lectins is presumed to be due to the formation of ion channels in the microbial membrane [60] or due to competitive inhibition of adhesion of microbial proteins to host polysaccharide receptors [61]. Lectin molecules are larger and include mannose-specific molecules obtained from an array of plants [62]. Lectins such as MAP30 from bitter melon [63], GAP31 from Gelonium multiflorum [64], and jacalin [65] are inhibitory on viral proliferation, including HIV and cytomegalovirus by potentially inhibiting viral interaction with critical host cell components. Due to the versatile antifungal, antibacterial, and antiviral functions delivered by these compounds, it is advantageous to investigate in depth their exact mechanism of action.

\section{Critical Antimicrobial Properties of PDAs}

3.1. Membrane Disruption and Impaired Cellular Metabolism. Although the exact mechanisms by which PDAs exert their antimicrobial action are not well defined, several potential methods have been reported. These include disruption of bacterial cell membrane leading to loss of membrane potential, impaired ATP production, and leakage of intracellular contents [66, 67]. Furthermore, chelation of metal ions, inhibition of membrane-bound ATPase, and altered membrane permeability brought about by PDAs affect normal physiology of bacteria and cause cell death $[12,32,34,68-$ 71]. Plant-derived antimicrobials such as carvacrol, thymol, eugenol, and catechins act by disruption of cell membrane, followed by the release of cell contents and loss of ATP [12, 70, $72,73]$. However, cinnamaldehyde has been reported to result in the depletion of intracellular ATP by inhibiting ATPase dependent energy metabolism along with the inhibition of glucose uptake and utilization $[32,69,70,74]$. Lysis of cell wall has also been documented in bacteria exposed to phenolic compounds $[32,75]$.

3.2. Antibiofilm Activity. Bacterial biofilms are surface-associated microbial communities enclosed in a self-generated exopolysaccharide matrix $[76,77]$. They are a cause of major concern, especially in the food industry and hospital environments due to their recalcitrance to commonly used antimicrobials and disinfectants [78-82], thereby resulting in human illnesses, including endocarditis, cystic fibrosis, and indwelling device-mediated infections [83].

Extensive research exploring the potential of alternative strategies for microbial biofilm control has highlighted the efficacy of several PDAs in controlling biofilm formation in major pathogens, including Listeria monocytogenes [84], Staphylococcus aureus [85-89], Pseudomonas aeruginosa [90, 91], Escherichia coli [92, 93], and Klebsiella pneumoniae [94]. Trans-cinnamaldehyde, an aromatic aldehyde obtained from bark of cinnamon trees, was found to inhibit biofilm formation and inactivate mature biofilm of Cronobacter sakazakii on feeding bottle coupons, stainless steel surfaces, and uropathogenic E. coli on urinary catheters [95, 96]. Similarly, terpenes such as carvacrol, thymol, and geraniol and essential oils of Cymbopogon citratus and Syzygium aromaticum were found to exhibit marked antibiofilm activity against both fungal [97-99] and bacterial biofilms [86, $87,100]$ encountered in food processing environments and biomedical settings.

As observed in antibiotics [101-103], PDAs at subinhibitory concentrations (SICs, concentrations not inhibiting the growth of microbes) are reported to modulate bacterial gene transcription $[84,96,104-106]$, which could be a contributing factor to their antibiofilm property. In a study by Amalaradjou and Venkitanarayanan [96], transcinnamaldehyde was found to modulate the transcription of genes critical for biofilm formation, motility, attachment, and quorum sensing in C. sakazakii. Similarly, Brackman and coworkers [107] observed the inhibitory effects of transcinnamaldehyde on biofilms of Vibrio spp. These authors found that trans-cinnamaldehyde was able to mitigate autoinducer 2 based quorum sensing and biofilm formation without inhibiting bacterial growth, probably due to its effect on gene transcription. Similar transcription modulatory effects have been observed in other major pathogens such as Salmonella [108] and P. aeruginosa [109] following exposure to PDAs. Since quorum sensing is one of the key processes involved in cell-to-cell communication and social behavior in microbes, the aforementioned reports could provide new insights into the development of novel therapeutics targeting key physiological processes in microbes.

Despite exhibiting effective antibiofilm properties, the use of PDAs has been thwarted by various confounding factors such as the requirement for more contact time, difficulty in administration, and organoleptic considerations when used on food contact surfaces. Therefore several researchers have investigated the efficacy of new delivery methods such as biodegradable polymers, micellar encapsulation, and polymeric films to potentiate the antibiofilm action of plant compounds. For example, micellar encapsulated eugenol and carvacrol were found to inhibit and inactivate L. monocytogenes and E. coli O157:H7 colony biofilms [110]. Similarly, reduced biofilm formation was observed on polymeric films containing carvacrol and cinnamaldehyde [88]. Nanoparticle-based drug delivery systems have been 
more frequently investigated for potentiating the antimicrobial efficacies of drugs [111]. The major advantages of nanoparticle-based drug delivery include sustained release, higher stability, and enhanced interaction of active ingredients with pathogens at their molecular level [112], thereby potentiating their antimicrobial action. The antimicrobial potential of nanoparticles containing plant-derived compounds such as trans-cinnamaldehyde, eugenol [113], and resveratrol [114] or essential oil of Nigella sativa [115] and garlic [116] has been recently investigated. These researchers found that nanoparticle formulations were more stable and highly effective in inhibiting the growth of major bacterial pathogens, including Salmonella and Listeria spp. Currently research is underway to investigate the potential of various nanoparticle-based delivery systems containing PDAs [117] for eradicating biofilms from hospital devices [118] and food processing environments [119]. In a recent study, Iannitelli and coworkers [117] prepared carvacrol encapsulated poly (DL-lactide-co-glycolide) (PLGA) nanoparticles and found that they were significantly effective in inactivating microbial biofilms of Staphylococcus epidermidis. In another study, PLGA containing cinnamaldehyde and carvacrol coatings were found to inhibit biofilms of E. coli, S. aureus, and P. aeruginosa [120].

3.3. Inhibiting Bacterial Capsule Production. Polysaccharide capsule is an important virulence determinant $[121,122]$ in many pathogenic bacteria, including Streptococcus pneumonia [123-125], S. aureus [126], K. pneumoniae [127], and Bacillus anthracis [128]. It protects bacteria from phagocytosis [123], thereby enhancing bacterial survival inside the host [126]. In addition, the presence of a capsule enhances bacterial adhesion and biofilm formation [129] in the environment $[10,130]$. Bacterial capsule has also been observed to cause pathology in plants. For example, capsular polysaccharide of Pseudomonas solanacearum was found to occlude xylem vessels resulting in plant death [131]. Since salicylic acid is a signal molecule involved in plant defense [132], several researchers have investigated the effect of salicylic acid [133] or its derivatives such as sodium salicylate [134], bismuth subsalicylate [135], and bismuth dimercaprol [136] on modulating bacterial capsule production. These researchers found that salicylic acid or its derivatives were effective in significantly reducing capsule production by modulating the expression of global regulators controlling capsular synthesis in S. aureus. Similar inhibitory effects have been observed with sub-MICs and MICs of various antibiotics [137-140]. Thus, plant-derived compounds represent a valuable resource for the development of therapeutics targeting bacterial capsule production.

3.4. Increasing Antibiotic Susceptibility in Drug Resistant Bacteria. As the understanding of antimicrobial resistance mechanisms in pathogens is increasing, multifold strategies to combat infections and reverse bacterial antibiotic resistance are being explored. Many researchers have reported PDAs as potential resistance modulating compounds, in addition to their inherent antimicrobial nature. In a study by Brehm-Stecher and Johnson [141], low concentrations of sesquiterpene such as nerolidol, bisabolol, and apritone increased bacterial sensitivity to multiple antibiotics, including ciprofloxacin, clindamycin, tetracycline, and vancomycin. Similarly, Dickson et al. [142] reported that plant extracts from Mezoneuron benthamianum, Securinega virosa, and Microglossa pyrifolia increased the susceptibility of major drug resistant fungi such as Trichophyton spp. and Microsporum gypseum and bacteria such as Salmonella spp., Klebsiella spp., $P$. aeruginosa, and $S$. aureus to norfloxacin. In addition, geraniol (present in essential oil of Helichrysum italicum) was found to restore the efficacy of quinolones, chloramphenicol, and $\beta$-lactams against multidrug resistant pathogens, including Acinetobacter baumannii [143]. Similar synergism was observed between antibiotics and various other medicinal plant extracts, including those of Camellia sinensis [144], Caesalpinia spinosa [145], oil of Croton zehntneri [146], carvacrol [147], and baicalein, the active component derived from Scutellaria baicalensis [148]. This modulatory effect of plant compounds is potentially due to the attenuation of three main resistance strategies employed by drug resistant pathogens to survive the action of antibiotics, namely, enzymatic degradation of antibiotics [149], alteration of antibiotic target site [150], and efflux pumps [151]. In addition, recent reports suggest that the combination therapy of antibiotics with PDAs acts through inhibition of multiple targets in various pathways critical for the normal functioning or virulence of the bacterial cell.

Generation of $\beta$-lactamase enzymes is an example of microbial strategy that is responsible for resistance to $\beta$ lactam antibiotics [152]. Several plant compounds have been identified with inhibitory activity towards $\beta$-lactamases [153]. Gangoué-Piéboji and coworkers [154] screened medicinal plants from Cameroon and found that extracts from Garcinia lucida and Bridelia micrantha exhibited significant inhibitory activity towards $\beta$-lactamases. Similarly, epigallocatechin gallate was found to inhibit penicillinase activity, thus increasing the sensitivity of $S$. aureus to penicillin [155] and augmenting the antimicrobial properties of ampicillin and sulbactam against Methicillin resistant $S$. aureus (MRSA).

Numerous studies in the past two decades have shown the efficacy of PDAs as potent efflux pump inhibitors against Gram-positive microbes [156-158]. Gram-negative bacteria pose an even greater challenge owing to the presence of potent efflux pumps, especially, AcrAB-TolC pumps [159]. In a recent investigation, five PDAs, namely, transcinnamaldehyde, $\beta$-resorcylic acid, carvacrol, thymol, and eugenol, or their combinations were found to increase the sensitivity of Salmonella enterica serotype Typhimurium phage type DT104 to five antibiotics [160]. Since the mechanism of antimicrobial resistance in Salmonella Typhimurium DT104 is mainly mediated by interaction between specific transporters of antibiotics and AcrAB-TolC efflux pump, the aforementioned plant compounds could be acting through modulation of these efflux pumps to increase the antibiotic sensitivity of the pathogen [161].

3.5. Attenuating Bacterial Virulence. The pathophysiology of microbial infection in a host is mediated by multiple virulence factors, which are expressed at different stages of 
infection to cause the disease. Reducing production of these virulence factors could control infections in humans. With major advancement in the fields of comparative genomics, transcriptomics, and proteomics, a better understanding of the key virulence mechanisms of pathogenic bacteria has been achieved. Thus, virulence factors are the prime targets for therapeutic interventions and vaccine development [11]. Quorum sensing controls the expression of genes encoding various virulence factors in many microorganisms $[162,163]$. A growing body of evidence suggests that plants produce antiquorum sensing compounds that interfere with cell-tocell communication, thereby downregulating the expression of virulence genes in microbes [164-166]. We previously reported that trans-cinnamaldehyde reduced the expression of luxR, which codes for transcriptional regulator of quorum sensing in C. sakazakii [96]. Similarly, Bodini and coworkers found that garlic extract and p-coumaric acid inhibited quorum sensing in quorum sensing reporter strains, indicating that plant compounds potentially modulate virulence by affecting quorum sensing in microbes.

For the majority of enteric pathogens, adhesion to and invasion of intestinal epithelium are critical for virulence and infection in a host. Specific proteins contribute to adhesion and invasion in various microbes. For example, Inl A and Inl B are surface proteins that facilitate receptor-mediated entry of L. monocytogenes in intestinal cells [167]. Several PDAs have been shown to reduce these virulence attributes in major food-borne pathogens such as L. monocytogenes [105], uropathogenic E. coli [168], and Salmonella enterica serovar Enteritidis [104] by downregulating the expression of virulence genes. In addition, reduction in capsule production has been documented in K. pneumoniae on exposure to PDAs [169], which affects its virulence and survival inside the host. These results highlight the ability of plant compounds to successfully target virulence factors critical for pathogenicity and pave the way for the development of compounds that target bacterial virulence.

3.6. Reducing Toxin Production. Microbial toxins are chemical compounds critical for virulence and pathogenesis in the host and therefore are prime targets for therapeutic interventions. Microbial toxins include exotoxins (secreted by the bacteria) and endotoxins (released after bacterial lysis), whereas mycotoxins are toxic secondary metabolites produced by fungi with diverse chemical structures and biological activities causing a variety of illnesses in humans. The drugs of choice for treating bacterial infections have been antibiotics; however the use of antibiotics to kill toxigenic microorganisms has several disadvantages such as resistance development [170], disruption of normal microbiota [171], and enhanced pathogenesis due to increased toxin production and cell lysis as observed in E. coli O157:H7 [172, 173]. Moreover, toxin-mediated pathogenesis can continue in the host even after bacterial clearance [174]. Therefore, antibiotics in general are contraindicated to treat toxigenic organisms and it is beneficial to employ an alternative approach to counteract the toxin-mediated virulence of pathogens.

In the past, plant extracts and their active molecules have proven effective against bacterial toxins produced by Vibrio spp., S. aureus, E. coli, and fungal toxins from Aspergillus spp. For example, a natural plant-derived dihydroisosteviol has been observed to prevent cholera toxin-mediated intestinal fluid secretion [175]. Plant polyphenols such as RG-tannin and apple phenols have been reported to inhibit ADPribosyltransferase activity critical for cholera toxin action $[176,177]$. These researchers also observed a reduction in the toxin induced fluid accumulation in mouse ileal loops. In a recent study by Yamasaki et al. [178], extracts from spices such as red chilli, sweet fennel, and white pepper were found to substantially inhibit the production of cholera toxin. These researchers found that capsaicin was an important component among the tested fractions and significantly reduced the expression of major virulence genes of $V$. cholerae, including $\operatorname{ctx} A, \operatorname{tcp} A$, and toxT. Similarly, eugenol, an essential oil from clove, was observed to significantly reduce the production of $S$. aureus $\alpha$-hemolysin, enterotoxins (SEA, SEB), and toxic shock syndrome toxin 1 [106]. Transcriptional analysis conducted by these researchers revealed a reduction in the expression of critical virulence genes (sea, seb, tst, and hla) involved in various aspects of $S$. aureus toxin production. Similarly, a compound from olive, 4-hydroxytyrosol, was found to successfully inactivate $S$. aureus endotoxin production in vitro [179].

Enterohemorrhagic E. coli (EHEC) is responsible for causing severe human infections, characterized by hemorrhagic colitis and hemorrhagic uremic syndrome [180]. In a recent study by Doughari and coworkers [181], extracts of Curtisia dentata were found to inhibit expression of $v t x 1$ and $v t x 2$ genes in EHEC. The extracts from this plant have been traditionally used as an antidiarrheal agent [182]. Similar verotoxin inhibitory activity was observed in other plant extracts such as Haematoxylon brasiletto [183], Limonium californicum (Boiss.), Cupressus lusitanica, Salvia urica Epling, and Jussiaea peruviana L. [184]. Inactivation of Shiga toxins by antitoxin antibodies [185] and by certain synthetic carbohydrate and peptide compounds designed to compete with the active site of the toxin for receptor sites on cell membranes has also been investigated [186-189]. Quiñones and coworkers [190] found that grape seed and grape pomace extracts exhibited strong anti-Shiga toxin-2 activity and conferred cellular protection against Shiga toxin2. Likewise, Daio (Rhei rhizoma), apple, hop bract, and green tea extracts have been shown previously to inhibit the release of Shiga toxin from E. coli O157:H7 [176, 191].

Aflatoxins, produced by Aspergillus flavus, A. parasiticus, A. nomius, A. tamari, A. bombycis, and A. pseudotamarii, cause both acute and chronic toxicity in humans and animals [192-195]. Common food products associated with mycotoxicosis include peanuts, corn grain, cottonseed [196, 197], chicken meat [198] cheese [199], canned mushrooms [200], raw milk [201, 202], and pork [203, 204]. Several studies have highlighted the efficacy of essential oils in reducing mycotoxin production. Crude aqueous extracts of garlic, carrot, and clove have been shown to exert a significant inhibitory effect on aflatoxin production in rice [205]. Capsanthin and capsaicin, the coloring and pungent ingredients of red chilli (Capsicum annum), completely inhibited both the growth and toxin production in A. flavus [206]. Mahmoud [207] 
studied the effect of several plant essential oils on growth and toxin production of $A$. flavus and found that five essential oils, namely, geraniol, nerol, citronellol, cinnamaldehyde, and thymol, completely suppressed the growth of A. flavus and prevented aflatoxin synthesis in a liquid medium. Similarly, curcumin and essential oil from Curcuma longa have also been reported to inhibit $A$. flavus toxin production [208]. In another study, cumin and clove oils have been found to exert inhibitory effects on toxin production in A. parasiticus [209], wherein aflatoxin production was decreased by $99 \%$. Similar findings have been observed with ochratoxin-producing aspergilli, where essential oil from wild thyme reduced ochratoxin production by more than $60 \%$ [210]. In addition, essential oils have been found to inhibit spore germination in toxin producing Aspergillus species [211]. In a recent study, Kumar and coworkers [212] demonstrated that amaryllin, a $15-\mathrm{kDa}$ antifungal protein from Amaryllis belladonna bulbs, exerts significant inhibitory effect against toxin producing $A$. flavus and Fusarium oxysporum. The aforementioned studies collectively suggest that plant polyphenols and other plant compounds are potential agents that can be used to protect humans against toxin-mediated food-borne diseases.

3.7. Beneficial Effects on Host Immune System. Pioneering research has demonstrated the existence of intriguing parallels between plant and animal immune responses against microbial infections. These include recognition of invariant pathogen-associated molecular patterns (PAMPs) [213], apoptosis of infected cells [214, 215], and production of antimicrobial peptides $[216,217]$. However, unlike microbespecific immune response in animals, plants depend on innate immunity of individual cells coupled with signals emanating from the site of infection $[28,218-220]$ to combat infections. This is mediated by the production of a wide variety of low molecular weight secondary metabolites [26, 221]. A mounting body of evidence suggests that plants extracts, in addition to their role in plant defense, exert immune-modulatory effects in animals [222, 223] and are increasingly being used for treating inflammatory diseases, allergy, and arthritis [224]. For example, tea tree [225, 226] and lavender oils [227] were found to ameliorate allergy symptoms by reducing histamine release [228, 229] and cytokine production [230]. The immune-modulatory effects of many PDAs have been demonstrated in mouse, chicken, and human cell lines [231-233]. Since the majority of the enteric pathogens colonize and invade the gut epithelium, followed by systemic spread via macrophages resulting in infection, the intestinal mucosal immune response (IMIS) is critical for conferring protection against such bacterial infections. A growing body of evidence suggests that PDAs in addition to attenuating bacterial virulence modulate IMIS $[224,234]$ through both nonspecific inflammatory response and antigen specific adaptive interactions in the intestine, thereby affecting pathogen survival. Plant preparations such as Eucalyptus oil [224], babassu mesocarp extract [235], and oil from seeds of Chenopodium ambrosioides L. [236] were found to activate the phagocytic activity of macrophages, whereas essential oils from Petroselinum crispum [234], Artemisia iwayomogi [237], and Jeju plant extract [116] were found to suppress activity of splenocytes and macrophages, indicating that the two oils may act through different mechanisms.

3.8. Beneficial Effects on Gastrointestinal Microflora. The human intestinal tract hosts a vast population of diverse bacterial communities that amount to as many as $10^{12}$ cells per $1 \mathrm{~g}$ of fecal mass in an average human being [238, 239]. The gut microbiota interacts with the host and influences various biological processes [240], including microbial defense [241]. With advances in high throughput sequencing and metagenomics and development of gnotobiotic animals, the ability to explore the variations in gut microbiota composition and their effect on human health has significantly improved [242, 243]. Modulations in dietary components have been associated with fluctuations in the composition of gut microbial population and diversity [244, 245], which in turn affects host's metabolic functions [246] and susceptibility to gastrointestinal bacterial infections [247]. David and coworkers [248] observed that short-term macronutrient variation leads to a change in the gut microbial community structure, with animal protein-based diet increasing the abundance of bile-tolerant microorganisms (Alistipes, Bilophila, and Bacteroides) and reducing the levels of Firmicutes that metabolize dietary plant polysaccharides (Roseburia, Eubacterium rectale, and Ruminococcus bromii). Bailey and group [249] demonstrated that stress exposure disrupted commensal microbial populations in the intestine of mice and led to increased colonization of Citrobacter rodentium. These researchers in their subsequent study observed that Lactobacillus reuteri attenuated the stress-enhanced severity of $C$. rodentium infection in mice [250]. Interestingly, recent studies have shown that PDAs that are highly bactericidal towards enteric pathogens exert low antimicrobial effect against commensal gut microbiota [251, 252]. Thapa and coworkers [253] found that nerolidol, thymol, eugenol, and geraniol inhibited growth of enteric pathogens such as E. coli O157:H7, Clostridium difficile, and S. Enteritidis. Moreover, the degree of inhibition was more on the pathogens than the commensal bacteria. Since PDAs and probiotics exert their antimicrobial effects by different mechanisms [254], a combinatorial approach using both could be more effective in controlling pathogens as compared to using them separately. However, research investigating their synergistic interactions is scanty. Further research is necessary to comprehensively elucidate the mechanism of action of such dietary interventions and their effect on gut microbiota for designing effective therapies that promote health by targeting diverse microbial communities.

\section{Challenges Associated with Using PDAs for Pathogen Control}

The efficacy of PDAs in controlling pathogens in the environment, high-risk foods, or their virulence in the host depends on various intrinsic and extrinsic factors. Physiochemical properties of PDAs such as solubility in aqueous solutions, hydrophobicity, biodegradability, and stabilities are major 
challenges that thwart their usage as natural biocontrol agents in the environment $[32,255]$. In addition, factors such as environmental temperature and atmospheric composition also modulate their antimicrobial efficacy [256]. In food products, the presence of fat [257], carbohydrates [258], and proteins [259] affects the efficacy of PDAs. Moreover, chemical variability in PDAs, originating from differences in extraction protocols [260, 261], affects the antimicrobial efficacy [12]. Another concern for PDAs is their strong aroma, which may modulate the organoleptic property and taste profile of food products. Therefore, careful selection of PDAs based on their chemical composition and effect on sensory attributes of food product is warranted before recommending their usage as food preservatives or direct oral supplements for human consumption [262].

\section{Future Directions}

With an increasing body of supporting literature, PDAs are now recognized to play a critical role in the development of effective therapeutics, either alone or in combination with conventional antibiotics. However, the major challenges to this include finding compounds with sufficiently lower MICs, low toxicity, and high bioavailability for effective and safe use in humans and animals.

Based on their modes of action, PDAs are classified into three categories, including conventional antimicrobials, multidrug resistance inhibitors, and compounds that target specific or multiple virulence factors in microbes [221]. As new approaches that target specific regulatory pathways and bacterial virulence are becoming the paradigm of antibacterial therapeutics in recent years, characterization of the mechanism of action of these compounds would pave the way for the development of novel drugs that can circumvent antimicrobial resistance and control infectious diseases.

\section{Conflict of Interests}

The authors declare that there is no conflict of interests regarding the publication of this paper.

\section{References}

[1] A. J. McMichael, "Environmental and social influences on emerging infectious diseases: past, present and future," Philosophical Transactions of the Royal Society B: Biological Sciences, vol. 359, no. 1447, pp. 1049-1058, 2004.

[2] F. A. Waldvogel, "Infectious diseases in the 21st century: old challenges and new opportunities," International Journal of Infectious Diseases, vol. 8, no. 1, pp. 5-12, 2004.

[3] N. D. Wolfe, C. P. Dunavan, and J. Diamond, "Origins of major human infectious diseases," Nature, vol. 447, no. 7142, pp. 279283, 2007.

[4] R. I. Aminov, "A brief history of the antibiotic era: lessons learned and challenges for the future," Frontiers in Microbiology, vol. 1, article 134, 2010.

[5] F. C. Tenover, "Mechanisms of antimicrobial resistance in bacteria," The American Journal of Medicine, vol. 119, no. 6, supplement 1, pp. S3-S10, 2006.
[6] E. Y. Furuya and F. D. Lowy, "Antimicrobial-resistant bacteria in the community setting," Nature Reviews Microbiology, vol. 4, no. 1, pp. 36-45, 2006.

[7] S. B. Levy, "Balancing the drug resistance equation," Trends in Microbiology, vol. 2, no. 10, pp. 341-342, 1994.

[8] D. M. Livermore, "Bacterial resistance: origins, epidemiology, and impact," Clinical Infectious Diseases, vol. 36, no. 1, pp. S11S23, 2003.

[9] S. Falkow, "What is a pathogen?" American Society for Microbiology, vol. 63, pp. 356-359, 1991.

[10] C. M. Taylor and I. S. Roberts, "Capsular polysaccharides and their role in virulence," Contributions to Microbiology, vol. 12, pp. 55-66, 2005.

[11] H. J. Wu, A. H. J. Wang, and M. P. Jennings, "Discovery of virulence factors of pathogenic bacteria," Current Opinion in Chemical Biology, vol. 12, pp. 1-9, 2008.

[12] S. Burt, "Essential oils: their antibacterial properties and potential applications in foods-a review," International Journal of Food Microbiology, vol. 94, no. 3, pp. 223-253, 2004.

[13] R. A. Holley and D. Patel, "Improvement in shelf-life and safety of perishable foods by plant essential oils and smoke antimicrobials," Food Microbiology, vol. 22, no. 4, pp. 273-292, 2005.

[14] G. J. E. Nychas and P. N. Skandamis, "Antimicrobials from herbs and spices," See Roller, vol. 17, pp. 177-200, 2003.

[15] A. E. Osbourn, "Preformed antimicrobial compounds and plant defense against fungal attack," Plant Cell, vol. 8, no. 10, pp. 18211831, 1996.

[16] S. Hoet, F. Opperdoes, R. Brun, and J. Quetin-Leclercq, "Natural products active against African trypanosomes: a step towards new drugs," Natural Product Reports, vol. 21, no. 3, pp. 353-364, 2004.

[17] S. Tagboto and S. Townson, "Antiparasitic properties of medicinal plants and other naturally occurring products," Advances in Parasitology, vol. 50, pp. 199-295, 2001.

[18] H. Ginsburg and E. Deharo, "A call for using natural compounds in the development of new antimalarial treatments-an introduction," Malaria Journal, vol. 10, article S1, supplement 1, 2011.

[19] M. L. Antony and S. V. Singh, "Molecular mechanisms and targets of cancer chemoprevention by garlic-derived bioactive compound diallyl trisulfide," Indian Journal of Experimental Biology, vol. 49, no. 11, pp. 805-816, 2011.

[20] R. J. Nash, A. Kato, C. Y. Yu, and G. W. Fleet, "Iminosugars as therapeutic agents: recent advances and promising trends," Future Medicinal Chemistry, vol. 3, no. 12, pp. 1513-1521, 2011.

[21] M. Shahid, A. Shahzad, F. Sobia et al., "Plant natural products as a potential source for antibacterial agents: recent trends," AntiInfective Agents in Medicinal Chemistry, vol. 8, no. 3, pp. 211-225, 2009.

[22] D. J. Newman, "Natural products as leads to potential drugs: an old process or the new hope for drug discovery?" Journal of Medicinal Chemistry, vol. 51, no. 9, pp. 2589-2599, 2008.

[23] D. J. Newman and G. M. Cragg, "Natural products as sources of new drugs over the 30 years from 1981 to 2010," Journal of Natural Products, vol. 75, no. 3, pp. 311-335, 2012.

[24] R. A. Dixon, "Natural products and plant disease resistance," Nature, vol. 411, no. 6839, pp. 843-847, 2001.

[25] J. Reichling, "Plant-microbe interactions and secondary metabolites with antibacterial, antifungal and antiviral properties," in Annual Plant Reviews, M. Wink, Ed., vol. 39 of Functions and 
Biotechnology of Plant Secondary Metabolites, chapter 4, Wiley, Oxford, UK, 2nd edition, 2010.

[26] J. D. G. Jones and J. L. Dangl, “The plant immune system," Nature, vol. 444, no. 7117, pp. 323-329, 2006.

[27] N. Stamp, "Out of the quagmire of plant defense hypotheses," Quarterly Review of Biology, vol. 78, no. 1, pp. 23-55, 2003.

[28] S. R. Hashemi and H. Davoodi, "Herbal plants as new immunostimulator In poultry industry: a review," Asian Journal of Animal and Veterinary Advances, vol. 7, no. 2, pp. 105-116, 2012.

[29] G. Han, X. Bingxiang, W. Xiaopeng et al., "Studies on active principles of Polyalthia nemoralis-I. The isolation and identification of natural zinc compound," Acta Chimica Sinica, vol. 39, pp. 433-437, 1981.

[30] B. E. van Wyk and N. Gericke, People's Plants, Briza Publications, Pretoria, South Africa, 2000.

[31] V. K. Juneja, H. P. Dwivedi, and X. Yan, "Novel natural food antimicrobials"," Annual Review of Food Science and Technology, vol. 3, no. 1, pp. 381-403, 2012.

[32] P. S. Negi, "Plant extracts for the control of bacterial growth: efficacy, stability and safety issues for food application," International Journal of Food Microbiology, vol. 156, no. 1, pp. 7-17, 2012.

[33] D. Savoia, "Plant-derived antimicrobial compounds: alternatives to antibiotics," Future Microbiology, vol. 7, no. 8, pp. 979990, 2012.

[34] M. M. Cowan, "Plant products as antimicrobial agents," Clinical Microbiology Reviews, vol. 12, no. 4, pp. 564-582, 1999.

[35] A. Kurek, A. M. Grudniak, A. Kraczkiewicz-Dowjat, and K. I. Wolska, "New antibacterial therapeutics and strategies," Polish Journal of Microbiology, vol. 60, no. 1, pp. 3-12, 2011.

[36] R. A. Dixon and C. L. Steele, "Flavonoids and isoflavonoids-a gold mine for metabolic engineering," Trends in Plant Science, vol. 4, no. 10, pp. 394-400, 1999.

[37] L. H. Cazarolli, L. Zanatta, E. H. Alberton et al., "Flavonoids: prospective drug candidates," Mini Reviews in Medicinal Chemistry, vol. 8, no. 13, pp. 1429-1440, 2008.

[38] C. P. Locher, M. T. Burch, H. F. Mower et al., "Anti-microbial activity and anti-complement activity of extracts obtained from selected Hawaiian medicinal plants," Journal of Ethnopharmacology, vol. 49, no. 1, pp. 23-32, 1995.

[39] F. Zeng, W. Wang, Y. Wu et al., "Two prenylated and Cmethylated flavonoids from Tripterygium wilfordii," Planta Medica, vol. 76, no. 14, pp. 1596-1599, 2010.

[40] R. P. Krämer, H. Hindorf, H. C. Jha, J. Kallage, and F. Zilliken, "Antifungal activity of soybean and chickpea isoflavones and their reduced derivatives," Phytochemistry, vol. 23, no. 10, pp. 2203-2205, 1984.

[41] P. M. Davidson and A. S. Naidu, "Phytophenols," in Natural Food Antimicrobial Systems, pp. 265-293, CRC Press, 2000.

[42] P. W. Taylor, J. M. T. Hamilton-Miller, and P. D. Stapleton, "Antimicrobial properties of green tea catechins," Food Science \& Technology Bulletin, vol. 2, pp. 71-81, 2005.

[43] A. Sher, "Antimicrobial activity of natural products from medicinal plants," Gomal Journal of Medical Sciences, vol. 7, no. 1, pp. 65-67, 2004.

[44] D. Ciocan and I. Bara, "Plant products as antimicrobial agents," Analele Ştiinţifice ale Universităţii "Alexandru Ioan Cuza" din Iaşi II A: Genetica si Biologie Moleculara, vol. 8, pp. 151-156, 2007.

[45] M. H. Kazmi, A. Malik, S. Hameed, N. Akhtar, and S. N. Ali, "An anthraquinone derivative from Cassia italica," Phytochemistry, vol. 36, no. 3, pp. 761-763, 1994.
[46] A. Scalbert, "Antimicrobial properties of tannins," Phytochemistry, vol. 30, no. 12, pp. 3875-3883, 1991.

[47] F. Saura-Calixto and J. Pérez-Jiménez, “Tannins: bioavailability and mechanisms of action," in Chemoprevention of Cancer and DNA Damage by Dietary Factors, S. Knasmüller, D. M. DeMarini, I. Johnson, and C. Gerhäuser, Eds., Wiley-VCH, Weinheim, Germany, 2009.

[48] C. Ya, S. H. Gaffney, T. H. Lilley, and E. Haslam, "Carbohydratepolyphenol and complexation," in Chemistry and Significance of Condensed Tannins, R. W. Hemingway and J. J. Karchesy, Eds., p. 553, Plenum Press, New York, NY, USA, 1998.

[49] E. Haslam, "Natural polyphenols (vegetable tannins) as drugs: possible modes of action," Journal of Natural Products, vol. 59, no. 2, pp. 205-215, 1996.

[50] K.-T. Chung, T. Y. Wong, C.-I. Wei, Y.-W. Huang, and Y. Lin, "Tannins and human health: a review," Critical Reviews in Food Science and Nutrition, vol. 38, no. 6, pp. 421-464, 1998.

[51] O. R. Kennedy and R. D. Thornes, Eds., Coumarins: Biology, Applications and Mode of Action, John Wiley \& Sons, New York, NY, USA, 1997.

[52] T. Namba, O. Morita, S.-L. Huang, K. Goshima, M. Hattori, and N. Kakiuchi, "Studies on cardio-active crude drugs; I. Effect of coumarins on cultured myocardial cells," Planta Medica, vol. 54, no. 4, pp. 277-282, 1988.

[53] A. García, V. Bocanegra-García, J. P. Palma-Nicolás, and G. Rivera, "Recent advances in antitubercular natural products," European Journal of Medicinal Chemistry, vol. 49, pp. 1-23, 2012.

[54] R. J. Fessenden and J. S. Fessenden, Organic Chemistry, Willard Grant Press, Boston, Mass, USA, 2nd edition, 1982.

[55] E. Omulokoli, B. Khan, and S. C. Chhabra, "Antiplasmodial activity of four Kenyan medicinal plants," Journal of Ethnopharmacology, vol. 56, no. 2, pp. 133-137, 1997.

[56] T. J. Maimone and P. S. Baran, "Modern synthetic efforts toward biologically active terpenes," Nature Chemical Biology, vol. 3, no. 7, pp. 396-407, 2007.

[57] A. Termentzi, N. Fokialakis, and A. L. Skaltsounis, "Natural resins and bioactive natural products as potential antimicrobial agents," Current Medicinal Chemistry, vol. 19, pp. 2292-2302, 2012.

[58] A. K. Balls, W. S. Hale, and T. H. Harris, "A crystalline protein obtained from a lipoprotein of wheat flour," Cereal Chemistry, vol. 19, pp. 279-288, 1942.

[59] M. F. C. De Bolle, R. W. Osborn, I. J. Goderis et al., "Antimicrobial peptides from Mirabilis jalapa and Amaranthus caudatus: expression, processing, localization and biological activity in transgenic tobacco," Plant Molecular Biology, vol. 31, no. 5, pp. 993-1008, 1996.

[60] Y. Zhang and K. Lewis, "Fabatins: new antimicrobial plant peptides," FEMS Microbiology Letters, vol. 149, no. 1, pp. 59-64, 1997.

[61] N. Sharon and I. Ofek, "Mannose specific bacterial surface lectins," in Microbial Lectins and Agglutinins, D. Mirelman, Ed., pp. 55-82, John Wiley \& Sons, New York, NY, USA, 1986.

[62] J. Balzarini, D. Schols, J. Neyts, E. van Damme, W. Peumans, and E. de Clercq, " $\alpha$-(1-3)- and $\alpha$-(1-6)-D-mannose-specific plant lectins are markedly inhibitory to human immunodeficiency virus and cytomegalovirus infections in vitro," Antimicrobial Agents and Chemotherapy, vol. 35, no. 3, pp. 410-416, 1991.

[63] S. Lee-Huang, P. L. Huang, H.-C. Chen et al., "Anti-HIV and anti-tumor activities of recombinant MAP30 from bitter melon," Gene, vol. 161, no. 2, pp. 151-156, 1995. 
[64] A. S. Bourinbaiar and S. Lee-Huang, "The activity of plantderived antiretroviral proteins MAP30 and GAP31 against herpes simplex virus infection in vitro," Biochemical and Biophysical Research Communications, vol. 219, no. 3, pp. 923-929, 1996.

[65] J. Favero, P. Corbeau, M. Nicolas et al., "Inhibition of human immunodeficiency virus infection by the lectin jacalin and by a derived peptide showing a sequence similarity with GP120," European Journal of Immunology, vol. 23, no. 1, pp. 179-185, 1993.

[66] H. Tsuchiya and M. Iinuma, "Reduction of membrane fluidity by antibacterial sophoraflavanone G isolated from Sophora exigua," Phytomedicine, vol. 7, no. 2, pp. 161-165, 2000.

[67] A. Plaper, M. Golob, I. Hafner, M. Oblak, T. Šolmajer, and R. Jerala, "Characterization of quercetin binding site on DNA gyrase," Biochemical and Biophysical Research Communications, vol. 306, no. 2, pp. 530-536, 2003.

[68] P. M. Davidson, "Chemical preservatives and natural antimicrobial compounds," in Food Microbiology: Fundamental and Frontiers, M. P. Doyle, L. R. Beuchat, and T. J. Montville, Eds., pp. 593-627, ASM Press, Washington, DC, USA, 2nd edition, 2001.

[69] A. O. Gill and R. A. Holley, "Mechanisms of bactericidal action of cinnamaldehyde against Listeria monocytogenes and of eugenol against L. monocytogenes and Lactobacillus sakei," Applied and Environmental Microbiology, vol. 70, no. 10, pp. 5750-5755, 2004.

[70] A. O. Gill and R. A. Holley, "Disruption of Escherichia coli, Listeria monocytogenes and Lactobacillus sakei cellular membranes by plant oil aromatics," International Journal of Food Microbiology, vol. 108, no. 1, pp. 1-9, 2006.

[71] A. O. Gill and R. A. Holley, "Inhibition of membrane bound ATPases of Escherichia coli and Listeria monocytogenes by plant oil aromatics," International Journal of Food Microbiology, vol. 111, no. 2, pp. 170-174, 2006.

[72] R. J. W. Lambert, P. N. Skandamis, P. J. Coote, and G.-J. E. Nychas, "A study of the minimum inhibitory concentration and mode of action of oregano essential oil, thymol and carvacrol," Journal of Applied Microbiology, vol. 91, no. 3, pp. 453-462, 2001.

[73] T. Hashimoto, S. Kumazawa, F. Nanjo, Y. Hara, and T. Nakayama, "Interaction of tea catechins with lipid bilayers investigated with liposome systems," Bioscience, Biotechnology and Biochemistry, vol. 63, no. 12, pp. 2252-2255, 1999.

[74] M. Oussalah, S. Caillet, and M. Lacroix, "Mechanism of action of Spanish oregano, Chinese cinnamon, and savory essential oils against cell membranes and walls of Escherichia coli O157:H7 and Listeria monocytogenes," Journal of Food Protection, vol. 69, no. 5, pp. 1046-1055, 2006.

[75] W. S. Borneman, D. E. Akin, and W. P. VanEseltine, "Effect of phenolic monomers on ruminal bacteria," Applied and Environmental Microbiology, vol. 52, no. 6, pp. 1331-1339, 1986.

[76] J. W. Costerton, Z. Lewandowski, D. E. Caldwell, D. R. Korber, and H. M. Lappin-Scott, "Microbial biofilms," Annual Review of Microbiology, vol. 49, pp. 711-745, 1995.

[77] M. E. Davey and G. A. O’Toole, "Microbial biofilms: from ecology to molecular genetics," Microbiology and Molecular Biology Reviews, vol. 64, pp. 847-867, 2000.

[78] R. A. N. Chmielewski and J. F. Frank, "Biofilm formation and control in food processing facilities," Comprehensive Reviews in Food Science and Food Safety, vol. 2, no. 1, pp. 22-32, 2003.

[79] H.-C. Flemming and J. Wingender, "The biofilm matrix," Nature Reviews Microbiology, vol. 8, no. 9, pp. 623-633, 2010.
[80] S. Langsrud, M. S. Sidhu, E. Heir, and A. L. Holck, "Bacterial disinfectant resistance-a challenge for the food industry," International Biodeterioration and Biodegradation, vol. 51, no. 4, pp. 283-290, 2003.

[81] M. Simoes and M. J. Vieira, "Persister cells in Pseudomonas fluorescens biofilms treated with a biocide," in Proceedings of the International Conference Processes in Biofilms: Fundamentals to Applications, pp. 58-62, Davis, Calif, USA, 2009.

[82] M. Simões, L. C. Simões, I. Machado, M. O. Pereira, and M. J. Vieira, "Control of flow-generated biofilms with surfactants: evidence of resistance and recovery," Food and Bioproducts Processing, vol. 84, no. 4, pp. 338-345, 2006.

[83] J. W. Costerton, P. S. Stewart, and E. P. Greenberg, "Bacterial biofilms: a common cause of persistent infections," Science, vol. 284, no. 5418, pp. 1318-1322, 1999.

[84] A. Upadhyay, I. Upadhyaya, A. Kollanoor-Johny, and K. Venkitanarayanan, "Antibiofilm effect of plant derived antimicrobials on Listeria monocytogenes," Food Microbiology, vol. 36, no. 1, pp. 79-89, 2013.

[85] A. G. Al-Bakri, G. Othman, and F. U. Afifi, "Determination of the antibiofilm, antiadhesive, and anti-MRSA activities of seven Salvia species," Pharmacognosy Magazine, vol. 6, no. 24, pp. 264-270, 2010.

[86] A. Nostro, A. S. Roccaro, G. Bisignano et al., "Effects of oregano, carvacrol and thymol on Staphylococcus aureus and Staphylococcus epidermidis biofilms," Journal of Medical Microbiology, vol. 56, no. 4, pp. 519-523, 2007.

[87] A. Nostro, A. Marino, A. R. Blanco et al., "In vitro activity of carvacrol against staphylococcal preformed biofilm by liquid and vapour contact," Journal of Medical Microbiology, vol. 58, no. 6, pp. 791-797, 2009.

[88] A. Nostro, R. Scaffaro, M. D’Arrigo et al., "Study on carvacrol and cinnamaldehyde polymeric films: mechanical properties, release kinetics and antibacterial and antibiofilm activities," Applied Microbiology and Biotechnology, vol. 96, no. 4, pp. 10291038, 2012.

[89] E. Walencka, S. Różalska, H. Wysokińska, M. Różalski, L. Kuźma, and B. Różalska, "Salvipisone and aethopinone from Salvia sclarea hairy roots modulate staphylococcal antibiotic resistance and express anti-biofilm activity," Planta Medica, vol. 73, pp. 545-551, 2007.

[90] H. Wu, B. Lee, L. Yang et al., "Effects of ginseng on Pseudomonas aeruginosa motility and biofilm formation," FEMS Immunology and Medical Microbiology, vol. 62, no. 1, pp. 49-56, 2011.

[91] K. Chang, D. Anderson, and A. Dan, "Inhibiting biofilm formation of Pseudomonas aeruginosa: A Two-Pronged Attack," Young Scientists Journal, vol. 2, no. 7, pp. 8-13, 2009.

[92] D. Ren, R. Zuo, A. F. G. Barrios et al., "Differential gene expression for investigation of Escherichia coli biofilm inhibition by plant extract ursolic acid," Applied and Environmental Microbiology, vol. 71, no. 7, pp. 4022-4034, 2005.

[93] A. M. Grudniak, A. Kurek, J. Szarlak, and K. I. Wolska, "Oleanolic and ursolic acids influence affect the expression of the cysteine regulon and the stress response in Escherichia coli," Current Microbiology, vol. 62, no. 4, pp. 1331-1336, 2011.

[94] S. Derakhshan, M. Sattari, and M. Bigdeli, "Effect of cumin (Cuminum cyminum) seed essential oil on biofilm formation and plasmid Integrity of Klebsiella pneumoniae," Pharmacognosy Magazine, vol. 6, no. 21, pp. 57-61, 2010.

[95] M. A. R. Amalaradjou, A. Narayanan, S. A. Baskaran, and K. Venkitanarayanan, "Antibiofilm effect of trans-cinnamaldehyde 
on uropathogenic Escherichia coli," The Journal of Urology, vol. 184, no. 1, pp. 358-363, 2010.

[96] M. A. R. Amalaradjou and K. Venkitanarayanan, "Effect of trans-cinnamaldehyde on inhibition and inactivation of Cronobacter sakazakii biofilm on abiotic surfaces," Journal of Food Protection, vol. 74, no. 2, pp. 200-208, 2011.

[97] S. Dalleau, E. Cateau, T. Bergès, J. M. Berjeaud, and C. Imbert, "In vitro activity of terpenes against Candida biofilms," International Journal of Antimicrobial Agents, vol. 31, no. 6, pp. 572-576, 2008.

[98] M. S. Khan and I. Ahmad, "Biofilm inhibition by Cymbopogon citratus and Syzygium aromaticum essential oils in the strains of Candida albicans," Journal of Ethnopharmacology, vol. 140, no. 2, pp. 416-423, 2012.

[99] M. S. A. Khan and I. Ahmad, "Antibiofilm activity of certain phytocompounds and their synergy with fluconazole against Candida albicans biofilms," Journal of Antimicrobial Chemotherapy, vol. 67, no. 3, pp. 618-621, 2012.

[100] J. R. Knowles, S. Roller, D. B. Murray, and A. S. Naidu, "Antimicrobial action of carvacrol at different stages of dual-species biofilm development by Staphylococcus aureus and Salmonella enterica serovar typhimurium," Applied and Environmental Microbiology, vol. 71, no. 2, pp. 797-803, 2005.

[101] E. B. Goh, G. Yim, W. Tsui, J. McClure, M. G. Surette, and J. Davies, "Transcriptional modulation of bacterial gene expression by subinhibitory concentrations of antibiotics," Proceedings of the National Academy of Sciences of the United States of America, vol. 99, no. 26, pp. 17025-17030, 2002.

[102] W. H. W. Tsui, G. Yim, H. H. M. Wang, J. E. McClure, M. G. Surette, and J. Davies, "Dual effects of MLS antibiotics: transcriptional modulation and interactions on the ribosome," Chemistry and Biology, vol. 11, no. 9, pp. 1307-1316, 2004.

[103] G. Yim, J. McClure, M. G. Surette, and J. E. Davies, "Modulation of Salmonella gene expression by subinhibitory concentrations of quinolones," Journal of Antibiotics, vol. 64, no. 1, pp. 73-78, 2011.

[104] A. Kollanoor-Johny, T. Mattson, S. A. Baskaran et al., "Reduction of Salmonella enterica serovar enteritidis colonization in 20-day-old broiler chickens by the plant-derived compounds trans-cinnamaldehyde and eugenol," Applied and Environmental Microbiology, vol. 78, no. 8, pp. 2981-2987, 2012.

[105] A. Upadhyay, A. K. Johny, M. A. R. Amalaradjou, S. Ananda Baskaran, K. S. Kim, and K. Venkitanarayanan, "Plant-derived antimicrobials reduce Listeria monocytogenes virulence factors in vitro, and down-regulate expression of virulence genes," International Journal of Food Microbiology, vol. 157, no. 1, pp. 8894, 2012.

[106] J. Qiu, H. Feng, J. Lu et al., "Eugenol reduces the expression of virulence-related exoproteins in Staphylococcus aureus," Applied and Environmental Microbiology, vol. 76, no. 17, pp. 5846-5851, 2010.

[107] G. Brackman, T. Defoirdt, C. Miyamoto et al., "Cinnamaldehyde and cinnamaldehyde derivatives reduce virulence in Vibrio spp. by decreasing the DNA-binding activity of the quorum sensing response regulator LuxR," BMC Microbiology, vol. 8, no. 1, article 149, 2008.

[108] Y. Zou, J. Woo, and J. Ahn, "Cellular and molecular responses of Salmonella typhimurium to antimicrobial-induced stresses during the planktonic-to-biofilm transition," Letters in Applied Microbiology, vol. 55, no. 4, pp. 274-282, 2012.

[109] T. H. Jakobsen, M. van Gennip, R. K. Phipps et al., "Ajoene, a sulfur-rich molecule from garlic, inhibits genes controlled by quorum sensing," Antimicrobial Agents and Chemotherapy, vol. 56, no. 5, pp. 2314-2325, 2012.

[110] D. Pérez-Conesa, L. McLandsborough, and J. Weiss, "Inhibition and inactivation of Listeria monocytogenes and Escherichia coli O157:H7 colony biofilms by micellar-encapsulated eugenol and carvacrol," Journal of Food Protection, vol. 69, no. 12, pp. 29472954, 2006.

[111] R. Singh and J. W. Lillard Jr., "Nanoparticle-based targeted drug delivery," Experimental and Molecular Pathology, vol. 86, no. 3, pp. 215-223, 2009.

[112] S. Gelperina, K. Kisich, M. D. Iseman, and L. Heifets, "The potential advantages of nanoparticle drug delivery systems in chemotherapy of tuberculosis," The American Journal of Respiratory and Critical Care Medicine, vol. 172, no. 12, pp. 14871490, 2005.

[113] C. Gomes, R. G. Moreira, and E. Castell-Perez, "Poly (DLlactide-co-glycolide) (PLGA) nanoparticles with entrapped trans-cinnamaldehyde and eugenol for antimicrobial delivery applications," Journal of Food Science, vol. 76, no. 2, pp. N16N24, 2011.

[114] V. Sanna, A. M. Roggio, S. Siliani et al., "Development of novel cationic chitosan-and anionic alginate-coated poly(D,L-lactideco-glycolide) nanoparticles for controlled release and light protection of resveratrol," International Journal of Nanomedicine, vol. 7, pp. 5501-5516, 2012.

[115] N. A. Alhaj, M. N. Shamsudin, N. M. Alipiah et al., "Characterization of Nigella sativa L. essential oil-loaded solid lipid nanoparticles," The American Journal of Pharmacology and Toxicology, vol. 5, no. 1, pp. 52-57, 2010.

[116] F.-L. Yang, X.-G. Li, F. Zhu, and C. L. Lei, "Structural characterization of nanoparticles loaded with garlic essential oil and their insecticidal activity against Tribolium castaneum (Herbst) (Coleoptera: Tenebrionidae)," Journal of Agricultural and Food Chemistry, vol. 57, no. 21, pp. 10156-10162, 2009.

[117] A. Iannitelli, R. Grande, A. di Stefano et al., "Potential antibacterial activity of carvacrol-loaded poly(DL-lactide-co-glycolide) (PLGA) nanoparticles against microbial biofilm," International Journal of Molecular Sciences, vol. 12, no. 8, pp. 5039-5051, 2011.

[118] S. Tamilvanan, N. Venkateshan, and A. Ludwig, "The potential of lipid- and polymer-based drug delivery carriers for eradicating biofilm consortia on device-related nosocomial infections," Journal of Controlled Release, vol. 128, no. 1, pp. 2-22, 2008.

[119] C. Ferreira, A. M. Pereira, L. Melo, and M. Simoes, "Advances in industrial biofilm control with micro-nanotechnology," in Current Research, Technology and Education. Applied Microbiology and Microbial Biotechnology, pp. 845-854, Formatex, 2010.

[120] K. R. Zodrow, J. D. Schiffman, and M. Elimelech, "Biodegradable polymer (PLGA) coatings featuring cinnamaldehyde and carvacrol mitigate biofilm formation," Langmuir, vol. 28, no. 39, pp. 13993-13999, 2012.

[121] E. R. Moxon and J. S. Kroll, “The role of bacterial polysaccharide capsules as virulence factors," Current Topics in Microbiology and Immunology, vol. 21, pp. 221-231, 1990.

[122] J. B. Robbins, W. B. Egan, W. Vann, and D. Liu, "Virulence properties of bacterial capsular polysaccharides-unanswered questions," in The Molecular Basis of Microbial Pathogenicity, $\mathrm{H}$. Smith, J. Skehel, and M. Turner, Eds., pp. 115-132, Verlag Chemie GmbH, Weinheim, Germany, 1980.

[123] C. Hyams, E. Camberlein, J. M. Cohen, K. Bax, and J. S. Brown, "The Streptococcus pneumoniae capsule inhibits complement activity and neutrophil phagocytosis by multiple mechanisms," Infection and Immunity, vol. 78, no. 2, pp. 704-715, 2010. 
[124] M. E. Sanders, E. W. Norcross, Z. M. Robertson, Q. C. Moore III, J. Fratkin, and M. E. Marquart, "The Streptococcus pneumoniae capsule is required for full virulence in pneumococcal endophthalmitis," Investigative Ophthalmology \& Visual Science, vol. 52, no. 2, pp. 865-872, 2011.

[125] J. Yother, "Capsules of Streptococcus pneumoniae and other bacteria: paradigms for polysaccharide biosynthesis and regulation," Annual Review of Microbiology, vol. 65, pp. 563-581, 2011.

[126] K. O’Riordan and J. C. Lee, "Staphylococcus aureus capsular polysaccharides," Clinical Microbiology Reviews, vol. 17, no. 1, pp. 218-234, 2004.

[127] D. Moranta, V. Regueiro, C. March et al., "Klebsiella pneumoniae capsule polysaccharide impedes the expression of $\beta$-defensins by airway epithelial cells," Infection and Immunity, vol. 78, no. 3, pp. 1135-1146, 2010.

[128] J. W. Ezzell and S. L. Welkos, "The capsule of Bacillus anthracis, a review," Journal of Applied Microbiology, vol. 87, no. 2, p. 250, 1999.

[129] C. Potera, "Forging a link between biofilms and disease," Science, vol. 283, no. 5409, pp. 1837-1839, 1999.

[130] E. B. Roberson and M. K. Firestone, "Relationship between desiccation and exopolysaccharide production in a soil Pseudomonas sp," Applied and Environmental Microbiology, vol. 58, no. 4, pp. 1284-1291, 1992.

[131] T. P. Denny and S. R. Baek, "Genetic evidence that extracellular polysaccharide is a virulence factor of Pseudomonas solanacearum," Molecular Plant-Microbe Interactions Journal, vol. 4, pp. 198-206, 1991.

[132] J. Shah, "The salicylic acid loop in plant defense," Current Opinion in Plant Biology, vol. 6, no. 4, pp. 365-371, 2003.

[133] L. P. Alvarez, M. S. Barbagelata, M. Gordiola, A. L. Cheung, D. O. Sordelli, and F. R. Buzzola, "Salicylic acid diminishes Staphylococcus aureus capsular polysaccharide type 5 expression," Infection and Immunity, vol. 78, no. 3, pp. 1339-1344, 2010.

[134] P. Domenico, T. Hopkins, P. E. Schoch, and B. A. Cunha, "Potentiation of aminoglycoside inhibition and reduction of capsular polysaccharide production in Klebsiella pneumoniae by sodium salicylate," Journal of Antimicrobial Chemotherapy, vol. 25, no. 6, pp. 903-914, 1990.

[135] P. Domenico, D. R. Landolphi, and B. A. Cunha, "Reduction of capsular polysaccharide and potentiation of aminoglycoside inhibition in Gram-negative bacteria by bismuth subsalicylate," Journal of Antimicrobial Chemotherapy, vol. 28, no. 6, pp. 801810, 1991.

[136] C.-T. Huang and P. S. Stewart, "Reduction of polysaccharide production in Pseudomonas aeruginosa biofilms by bismuth dimercaprol (BisBAL) treatment," Journal of Antimicrobial Chemotherapy, vol. 44, no. 5, pp. 601-605, 1999.

[137] F. Farzam and B. J. Plotkin, "Effect of sub-MICs of antibiotics on the hydrophobicity and production of acidic polysaccharide by Vibrio vulnificus," Chemotherapy, vol. 47, no. 3, pp. 184-193, 2001.

[138] T. K. Held, C. Adamczik, M. Trautmann, and A. S. Cross, "Effects of MICs and sub-MICs of antibiotics on production of capsular polysaccharide of Klebsiella pneumoniae," Antimicrobial Agents and Chemotherapy, vol. 39, no. 5, pp. 1093-1096, 1995.

[139] P. Williams, "Sub-MICs of cefuroxime and ciprofloxacin influence interaction of complement and immunoglobulins with Klebsiella pneumoniae," Antimicrobial Agents and Chemother$a p y$, vol. 31, no. 5, pp. 758-762, 1987.
[140] S. Suerbaum, H. Leying, H.-P. Kroll, J. Gmeiner, and W. Opferkuch, "Influence of $\beta$-lactam antibiotics and ciprofloxacin on cell envelope of Escherichia coli," Antimicrobial Agents and Chemotherapy, vol. 31, no. 7, pp. 1106-1110, 1987.

[141] B. F. Brehm-Stecher and E. A. Johnson, "Sensitization of Staphylococcus aureus and Escherichia coli to antibiotics by the sesquiterpenoids nerolidol, farnesol, bisabolol, and apritone," Antimicrobial Agents and Chemotherapy, vol. 47, no. 10, pp. 3357-3360, 2003.

[142] R. A. Dickson, P. J. Houghton, P. J. Hylands, and S. Gibbons, "Antimicrobial, resistance-modifying effects, antioxidant and free radical scavenging activities of Mezoneuron benthamianum Baill., Securinega virosa Roxb. \& Wlld. and Microglossa pyrifolia Lam.," Phytotherapy Research, vol. 20, no. 1, pp. 41-45, 2006.

[143] V. Lorenzi, A. Muselli, A. F. Bernardini et al., "Geraniol restores antibiotic activities against multidrug-resistant isolates from gram-negative species," Antimicrobial Agents and Chemotherapy, vol. 53, no. 5, pp. 2209-2211, 2009.

[144] F. Aqil, M. S. A. Khan, M. Owais, and I. Ahmad, "Effect of certain bioactive plant extracts on clinical isolates of $\beta$-lactamase producing methicillin resistant Staphylococcus aureus," Journal of Basic Microbiology, vol. 45, no. 2, pp. 106-114, 2005.

[145] K. Kondo, Y. Takaishi, H. Shibata, and T. Higuti, "ILSMRs (intensifier of $\beta$-lactam-susceptibility in methicillin- resistant Staphylococcus aureus) from Tara [Caesalpinia spinosa (Molina) Kuntze]," Phytomedicine, vol. 13, no. 3, pp. 209-212, 2006.

[146] F. F. G. Rodrigues, J. G. M. Costa, and H. D. M. Coutinho, "Synergy effects of the antibiotics gentamicin and the essential oil of Croton zehntneri," Phytomedicine, vol. 16, no. 11, pp. 10521055, 2009.

[147] M. J. Grande, R. L. López, H. Abriouel et al., "Treatment of vegetable sauces with enterocin AS-48 alone or in combination with phenolic compounds to inhibit proliferation of Staphylococcus aureus," Journal of Food Protection, vol. 70, no. 2, pp. 405411, 2007.

[148] B. C. L. Chan, M. Ip, C. B. S. Lau et al., "Synergistic effects of baicalein with ciprofloxacin against NorA over-expressed methicillin-resistant Staphylococcus aureus (MRSA) and inhibition of MRSA pyruvate kinase," Journal of Ethnopharmacology, vol. 137, no. 1, pp. 767-773, 2011.

[149] J. Davies, "Inactivation of antibiotics and the dissemination of resistance genes," Science, vol. 264, no. 5157, pp. 375-382, 1994.

[150] B. G. Spratt, "Resistance to antibiotics mediated by target alterations," Science, vol. 264, no. 5157, pp. 388-393, 1994.

[151] H. Nikaido, "Porins and specific diffusion channels in bacterial outer membranes," The Journal of Biological Chemistry, vol. 269, no. 6, pp. 3905-3908, 1994.

[152] J.-M. Frère, "Beta-lactamases and bacterial resistance to antibiotics," Molecular Microbiology, vol. 16, no. 3, pp. 385-395, 1995.

[153] M. Jiminez-Valera, A. Ruiz-Bravo, and A. Ramos-Cormenzana, "Inhibition of $\beta$-lactamases from Yersinia enterocolitica by plant extracts," Journal of Antimicrobial Chemotherapy, vol. 19, no. 1, pp. 31-37, 1987.

[154] J. Gangoué-Piéboji, S. Baurin, J.-M. Frère et al., "Screening of some medicinal plants from Cameroon for $\beta$-lactamase inhibitory activity," Phytotherapy Research, vol. 21, no. 3, pp. 284-287, 2007.

[155] W. H. Zhao, Z. Q. Hu, Y. Hara, and T. Shimamura, "Inhibition of penicillinase by epigallocatechin gallate resulting in restoration of antibacterial activity of penicillin against penicillinaseproducing Staphylococcus aureus," Antimicrobial Agents and Chemotherapy, vol. 46, no. 7, pp. 2266-2268, 2002. 
[156] L. Chérigo, R. Pereda-Miranda, M. Fragoso-Serrano, N. JacoboHerrera, G. W. Kaatz, and S. Gibbons, "Inhibitors of bacterial multidrug efflux pumps from the resin glycosides of Ipomoea murucoides," Journal of Natural Products, vol. 71, no. 6, pp. 10371045, 2008.

[157] A. Kumar, I. A. Khan, S. Koul et al., "Novel structural analogues of piperine as inhibitors of the NorA efflux pump of Staphylococcus aureus," Journal of Antimicrobial Chemotherapy, vol. 61, no. 6, pp. 1270-1276, 2008.

[158] J. G. Holler, S. B. Christensen, H.-C. Slotved et al., "Novel inhibitory activity of the Staphylococcus aureus NorA efflux pump by a kaempferol rhamnoside isolated from Persea lingue nees," Journal of Antimicrobial Chemotherapy, vol. 67, no. 5, pp. 1138-1144, 2012.

[159] L. J. V. Piddock, "Clinically relevant chromosomally encoded multidrug resistance efflux pumps in bacteria," Clinical Microbiology Reviews, vol. 19, no. 2, pp. 382-402, 2006.

[160] A. K. Johny, T. Hoagland, and K. Venkitanarayanan, "Effect of subinhibitory concentrations of plant-derived molecules in increasing the sensitivity of multidrug-resistant Salmonella enterica Serovar Typhimurium DT104 to antibiotics," Foodborne Pathogens and Disease, vol. 7, no. 10, pp. 1165-1170, 2010.

[161] T. Quinn, R. O’Mahony, A. W. Baird, D. Drudy, P. Whyte, and S. Fanning, "Multi-drug resistance in Salmonella enterica: efflux mechanisms and their relationships with the development of chromosomal resistance gene clusters," Current Drug Targets, vol. 7, no. 7, pp. 849-860, 2006.

[162] L. C. M. Antunes and R. B. R. Ferreira, "Intercellular communication in bacteria," Critical Reviews in Microbiology, vol. 35, no. 2, pp. 66-80, 2009.

[163] R. P. Novick and E. Geisinger, "Quorum sensing in staphylococci," Annual Review of Genetics, vol. 42, pp. 541-564, 2008.

[164] A. L. Adonizio, K. Downum, B. C. Bennett, and K. Mathee, "Anti-quorum sensing activity of medicinal plants in Southern Florida," Journal of Ethnopharmacology, vol. 105, no. 3, pp. 427435, 2006.

[165] W. D. Bauer and U. Mathesius, "Plant responses to bacterial quorum sensing signals," Current Opinion in Plant Biology, vol. 7, no. 4, pp. 429-433, 2004.

[166] M. Teplitski, J. B. Robinson, and W. D. Bauer, "Plants secrete substances that mimic bacterial $\mathrm{N}$-acyl homoserine lactone signal activities and affect population density-dependent behaviors in associated bacteria," Molecular Plant-Microbe Interactions, vol. 13, no. 6, pp. 637-648, 2000.

[167] D. A. Portnoy, T. Chakraborty, W. Goebel, and P. Cossart, "Molecular determinants of Listeria monocytogenes pathogenesis," Infection and Immunity, vol. 60, no. 4, pp. 1263-1267, 1992.

[168] M. A. R. Amalaradjou, A. Narayanan, and K. Venkitanarayanan, "Trans-cinnamaldehyde decreases attachment and invasion of uropathogenic Escherichia coli in urinary tract epithelial cells by modulating virulence gene expression," Journal of Urology, vol. 185, no. 4, pp. 1526-1531, 2011.

[169] S. Derakhshan, M. Sattari, and M. Bigdeli, "Effect of subinhibitory concentrations of cumin (Cuminum cyminum L.) seed essential oil and alcoholic extract on the morphology, capsule expression and urease activity of Klebsiella pneumoniae," International Journal of Antimicrobial Agents, vol. 32, no. 5, pp. 432436, 2008.

[170] D. A. Rasko and V. Sperandio, "Anti-virulence strategies to combat bacteria-mediated disease," Nature Reviews Drug Discovery, vol. 9, no. 2, pp. 117-128, 2010.
[171] C. Jernberg, S. Löfmark, C. Edlund, and J. K. Jansson, "Longterm impacts of antibiotic exposure on the human intestinal microbiota," Microbiology, vol. 156, no. 11, pp. 3216-3223, 2010.

[172] J. N. Walterspiel, S. Ashkenazi, A. L. Morrow, and T. G. Cleary, "Effect of subinhibitory concentrations of antibiotics on extracellular shiga-like toxin I," Infection, vol. 20, no. 1, pp. 2529, 1992.

[173] C. S. Wong, S. Jelacic, R. L. Habeeb, S. L. Watkins, and P. I. Tarr, "The risk of the hemolytic-uremic syndrome after antibiotic treatment of Escherichia coli O157:H7 infections," The New England Journal of Medicine, vol. 342, no. 26, pp. 1930-1936, 2000.

[174] J. C. Burnett, J. J. Schmidt, C. F. McGrath et al., "Conformational sampling of the botulinum neurotoxin serotype a light chain: Implications for inhibitor binding," Bioorganic and Medicinal Chemistry, vol. 13, no. 2, pp. 333-341, 2005.

[175] P. Pariwat, S. Homvisasevongsa, C. Muanprasat, and V. Chatsudthipong, "A natural plant-derived dihydroisosteviol prevents cholera toxin-induced intestinal fluid secretion," Journal of Pharmacology and Experimental Therapeutics, vol. 324, no. 2, pp. 798-805, 2008.

[176] N. Morinaga, Y. Iwamarul, K. Yahiro, M. Tagashira, J. Moss, and M. Noda, "Differential activities of plant polyphenols on the binding and internalization of cholera toxin in vero cells," The Journal of Biological Chemistry, vol. 280, no. 24, pp. 2330323309, 2005.

[177] T. Saito, M. Miyake, M. Toba, H. Okamatsu, S. Shimizu, and M. Noda, "Inhibition by apple polyphenols of ADPribosyltransferase activity of cholera toxin and toxin-induced fluid accumulation in mice," Microbiology and Immunology, vol. 46, no. 4, pp. 249-255, 2002.

[178] S. Yamasaki, M. Asakura, S. B. Neogi, A. Hinenoya, E. Iwaoka, and S. Aoki, "Inhibition of virulence potential of Vibrio cholerae by natural compounds," Indian Journal of Medical Research, vol. 133, no. 2, pp. 232-239, 2011.

[179] M. Friedman, R. Rasooly, P. M. Do, and P. R. Henika, "The olive compound 4-hydroxytyrosol inactivates Staphylococcus aureus bacteria and Staphylococcal Enterotoxin A (SEA)," Journal of Food Science, vol. 76, no. 8, pp. M558-M563, 2011.

[180] C. Welinder-Olsson and B. Kaijser, "Enterohemorrhagic Escherichia coli (EHEC)," Scandinavian Journal of Infectious Diseases, vol. 37, no. 6-7, pp. 405-416, 2005.

[181] J. H. Doughari, P. A. Ndakidemi, I. S. Human, and S. Benade, "Antioxidant, antimicrobial and antiverotoxic potentials of extracts of Curtisia dentata," Journal of Ethnopharmacology, vol. 141, no. 3, pp. 1041-1050, 2012.

[182] A. Notten, "Curtisi dentate (Burm.f.) C.A.Sm.," South African National Biodiversity Institutes plant information website, 2004, http://www.plantzafrica.com/.

[183] N. Heredia, M. Escobar, C. Rodríguez-Padilla, and S. García, "Extracts of Haematoxylon brasiletto inhibit growth, verotoxin production, and adhesion of enterohemorrhagic Escherichia coli O157:H7 to HeLa cells," Journal of Food Protection, vol. 68, no. 7, pp. 1346-1351, 2005.

[184] Y. Sakagami, H. Murata, T. Nakanishi et al., "Inhibitory effect of plant extracts on production of verotoxin by enterohemorrhagic Escherichia coli O157:H7," Journal of Health Science, vol. 47, no. 5, pp. 473-477, 2001.

[185] G. Krautz-Peterson, S. Chapman-Bonofiglio, K. Boisvert et al., "Intracellular neutralization of Shiga toxin 2 by an A subunitspecific human monoclonal antibody," Infection and Immunity, vol. 76, no. 5, pp. 1931-1939, 2008. 
[186] K. Ikeda, K. Nagasawa, T. Horiuchi, T. Tsuru, H. Nishizaka, and Y. Niho, "C5a induces tissue factor activity on endothelial cells," Thrombosis and Haemostasis, vol. 77, no. 2, pp. 394-398, 1997.

[187] J. B. Saenz, T. A. Doggett, and D. B. Haslam, "Identification and characterization of small molecules that inhibit intracellular toxin transport," Infection and Immunity, vol. 75, no. 9, pp. 45524561, 2007.

[188] P. I. Kitov, T. Lipinski, E. Paszkiewicz et al., "An entropically efficient supramolecular inhibition strategy for Shiga toxins," Angewandte Chemie, vol. 47, no. 4, pp. 672-676, 2008.

[189] P. I. Kitov, G. L. Mulvey, T. P. Griener et al., "In vivo supramolecular templating enhances the activity of multivalent ligands: a potential therapeutic against the Escherichia coli $\mathrm{O} 157 \mathrm{AB} 5$ toxins," Proceedings of the National Academy of Sciences of the United States of America, vol. 105, no. 44, pp. 16837-16842, 2008.

[190] B. Quiñones, S. Massey, M. Friedman, M. S. Swimley, and K. Teter, "Novel cell-based method to detect shiga toxin 2 from escherichia coli O157:H7 and inhibitors of toxin activity," Applied and Environmental Microbiology, vol. 75, no. 5, pp. 14101416, 2009.

[191] H. Oi, D. Matsuura, M. Miyake et al., "Identification in traditional herbal medications and confirmation by synthesis of factors that inhibit cholera toxin-induced fluid accumulation," Proceedings of the National Academy of Sciences of the United States of America, vol. 99, no. 5, pp. 3042-3046, 2002.

[192] C. P. Kurtzman, B. W. Horn, and C. W. Hesseltine, "Aspergillus nomius, a new aflatoxin-producing species related to Aspergillus flavus and Aspergillus tamarii," Antonie van Leeuwenhoek, vol. 53, no. 3, pp. 147-158, 1987.

[193] I. Dvorackova, Aflatoxins and Human Health, CRC Press, Boca Raton, Fla, USA, 1990.

[194] T. Goto, D. T. Wicklow, and Y. Ito, "Aflatoxin and cyclopiazonic acid production by a sclerotium-producing Aspergillus tamarii strain," Applied and Environmental Microbiology, vol. 62, no. 11, pp. 4036-4038, 1996.

[195] S. W. Peterson, Y. Ito, B. W. Horn, and T. Goto, “Aspergillus bombycis, a new aflatoxigenic species and genetic variation in its sibling species, A. nomius," Mycologia, vol. 93, no. 4, pp. 689703, 2001.

[196] H. Oǧuz, V. Kurtoğlu, and B. Coşkun, "Preventive efficacy of clinoptilolite in broilers during chronic aflatoxin (50 and 100 ppb) exposure," Research in Veterinary Science, vol. 69, no. 2, pp. 197-201, 2000.

[197] E. Sur and I. Celik, "Effects of aflatoxin B1 on the development of the bursa of Fabricius and blood lymphocyte acid phosphatase of the chicken," British Poultry Science, vol. 44, no. 4, pp. 558566, 2003.

[198] R. M. Resanovic, K. D. Nešic, V. D. Nesic, T. D. Palic, and V. M. Jacevic, "Mycotoxins in poultry production," Zbornik Matice Srpske za Prirodne Nauke, vol. 116, pp. 7-14, 2009.

[199] N. Ertas, Z. Gonulalan, Y. Yildirim, and E. Kum, "Detection of Staphylococcus aureus enterotoxins in sheep cheese and dairy desserts by multiplex PCR technique," International Journal of Food Microbiology, vol. 142, no. 1-2, pp. 74-77, 2010.

[200] A. S. M. Kamal, A. Khair, M. Dawlatana, M. T. Hassan, F. Begum, and M. Rahim, "Evaluation of aflatoxins and pesticide residues in fresh and different processed mushrooms," Bangladesh Journal of Scientific and Industrial Research, vol. 44, no. 2, pp. 193-198, 2009.

[201] B. El Marnissi, R. Belkhou, D. P. Morgavi, L. Bennani, and H. Boudra, "Occurrence of aflatoxin M1 in raw milk collected from traditional dairies in Morocco," Food and Chemical Toxicology, vol. 50, no. 8, pp. 2819-2821, 2012.

[202] I. Hussain and J. Anwar, "A study on contamination of aflatoxin $\mathrm{M}_{1}$ in raw milk in the Punjab province of Pakistan," Food Control, vol. 19, no. 4, pp. 393-395, 2008.

[203] D. E. Carrier, "Prevention of aflatoxicosis by addition of hydrated sodium calcium aluminosilicate to the diets of growing barrows," American Journal of Veterinary Research, vol. 50, no. 3, pp. 416-420, 1989.

[204] M. D. Lindemann, D. J. Blodgett, E. T. Kornegay, and G. G. Schurig, "Potential ameliorators of aflatoxicosis in weanling/growing swine," Journal of animal science, vol. 71, no. 1, pp. 171-178, 1993.

[205] D. Thanaboripat, K. Nontabenjawan, K. Lessin, D. Teerapiannont, O. Sukchareon, and V. Ruangrattanamatee, "Inhibitory effects of garlic, clove and carrot ongrowth of Aspergillus flavus and aflatoxin production," Journal Canadien de la Recherche Forestière, vol. 8, pp. 39-42, 1997.

[206] A. Masood, J. V. V. Dogra, and A. K. Jha, "The influence of colouring and pungent agents of red Chilli (Capsicum annum) on growth and aflatoxin production by Aspergillus flavus," Letters in Applied Microbiology, vol. 18, no. 4, pp. 184-186, 1994.

[207] A. L. Mahmoud, "Antifungal action and antiaflatoxigenic properties of some essential oil constituents," Letters in Applied Microbiology, vol. 19, no. 2, pp. 110-113, 1994.

[208] F. D. Ferreira, C. Kemmelmeier, C. C. Arrotéia et al., "Inhibitory effect of the essential oil of Curcuma longa L. and curcumin on aflatoxin production by Aspergillus flavus Link," Food Chemistry, vol. 136, no. 2, pp. 789-793, 2013.

[209] R. S. Farag, Z. Y. Daw, and S. H. Abo-Raya, "Influence of some spice essential oils on Aspergillus parasiticus growth and production of aflatoxins in a synthetic medium," Journal of Food Science, vol. 54, no. 1, pp. 74-76, 1989.

[210] D. Sokolić-Mihalak, J. Frece, A. Slavica, F. Delaš, H. Pavlović, and K. Markov, "The effects Of wild Thyme (Thymus Serpyllum L.) essential oil components against Ochratoxin-Producing Aspergilli/Majčina Dušica (Thymus Serpyllum L.) I Njezine Komponente Protiv Okratoksikotvornih Vrsta Aspergillusa," Archives of Industrial Hygiene and Toxicology, vol. 63, no. 4, pp. 457-462, 2012.

[211] N. Gemeda, Y. Woldeamanuel, D. Asrat, and A. Debella, "Effect of essential oils on Aspergillus spore germination, growth and mycotoxin production: a potential source of botanical food preservative," Asian Pacific Journal of Tropical Biomedicine, vol. 4, supplement 1, pp. S373-S381, 2014.

[212] S. Kumar, N. Singh, M. Sinha et al., "Isolation, purification, crystallization and preliminary crystallographic studies of amaryllin, a plant pathogenesis-related protein from Amaryllis belladonna," Acta Crystallographica F: Structural Biology and Crystallization Communications, vol. 65, no. 6, pp. 635-637, 2009.

[213] T. Nürnberger, F. Brunner, B. Kemmerling, and L. Piater, "Innate immunity in plants and animals: striking similarities and obvious differences," Immunological Reviews, vol. 198, pp. 249-266, 2004.

[214] N. Palavan-Unsal, E. D. Buyuktuncer, and M. A. Tufekci, "Programmed cell death in plants," Journal of Molecular Cell Biology, vol. 4, pp. 9-23, 2005.

[215] B. F. Vanyushin, L. E. Bakeeva, V. A. Zamyatnina, and N. I. Aleksandrushkina, "Apoptosis in plants: specific features of plant apoptotic cells and effect of various factors and agents," International Review of Cytology, vol. 233, pp. 135-179, 2004. 
[216] W. F. Broekaert, B. P. A. Cammue, M. F. C. de Bolle, K. Thevissen, G. W. de Samblanx, and R. W. Osborn, "Antimicrobial peptides from plants," Critical Reviews in Plant Sciences, vol. 16, no. 3, pp. 297-323, 1997.

[217] P. B. Pelegrini, R. P. D. Sarto, O. N. Silva, O. L. Franco, and M. F. Grossi-de-Sa, "Antibacterial peptides from plants: what they are and how they probably work," Biochemistry Research International, vol. 2011, Article ID 250349, 9 pages, 2011.

[218] J. L. Dangl and J. D. G. Jones, "Plant pathogens and integrated defence responses to infection," Nature, vol. 411, no. 6839, pp. 826-833, 2001.

[219] F. M. Ausubel, "Are innate immune signaling pathways in plants and animals conserved?" Nature Immunology, vol. 6, no. 10, pp. 973-979, 2005.

[220] S. T. Chisholm, G. Coaker, B. Day, and B. J. Staskawicz, "Host-microbe interactions: shaping the evolution of the plant immune response," Cell, vol. 124, no. 4, pp. 803-814, 2006.

[221] K. Lewis and F. M. Ausubel, "Prospects for plant-derived antibacterials," Nature Biotechnology, vol. 24, no. 12, pp. 15041507, 2006.

[222] S. R. Hashemi, I. Zulkifli, Z. Zunita, and M. N. Somchit, "The effect of selected sterilization methods on antibacterial activity of aqueous extract of herbal plants," Journal of Biological Sciences, vol. 8, no. 6, pp. 1072-1076, 2008.

[223] S. R. Hashemi and H. Davoodi, "Herbal plants and their derivatives as growth and health promoters in animal nutrition," Veterinary Research Communications, vol. 35, no. 3, pp. 169-180, 2011.

[224] A. Serafino, P. S. Vallebona, F. Andreola et al., "Stimulatory effect of Eucalyptus essential oil on innate cell-mediated immune response," BMC Immunology, vol. 9, article 17, 2008.

[225] C. Brand, M. A. Grimbaldeston, J. R. Gamble, J. Drew, J. J. Finlay-Jones, and P. H. Hart, "Tea tree oil reduces the swelling associated with the efferent phase of a contact hypersensitivity response," Inflammation Research, vol. 51, no. 5, pp. 236-244, 2002.

[226] P. H. Hart, C. Brand, C. F. Carson, T. V. Riley, R. H. Prager, and J. J. Finlay-Jones, "Terpinen-4-ol, the main component of the essential oil of Melaleuca alternifolia (tea tree oil), suppresses inflammatory mediator production by activated human monocytes," Inflammation Research, vol. 49, no. 11, pp. 619-626, 2000.

[227] H.-M. Kim and S.-H. Cho, "Lavender oil inhibits immediatetype allergic reaction in mice and rats," Journal of Pharmacy and Pharmacology, vol. 51, no. 2, pp. 221-226, 1999.

[228] C. Brand, S. L. Townley, J. J. Finlay-Jones, and P. H. Hart, "Tea tree oil reduces histamine-induced oedema in murine ears," Inflammation Research, vol. 51, no. 6, pp. 283-289, 2002.

[229] F. A. Santos and V. S. N. Rao, "Mast cell involvement in the rat paw oedema response to 1,8-cineole, the main constituent of eucalyptus and rosemary oils," European Journal of Pharmacology, vol. 331, no. 2-3, pp. 253-258, 1997.

[230] C. Brand, A. Ferrante, R. H. Prager et al., "The water-soluble components of the essential oil of Melaleuca alternifolia (tea tree oil) suppress the production of superoxide by human monocytes, but not neutrophils, activated in vitro," Inflammation Research, vol. 50, no. 4, pp. 213-219, 2001.

[231] B. E. Shan, Y. Yoshida, T. Sugiura, and U. Yamashita, "Stimulating activity of Chinese medicinal herbs on human lymphocytes in vitro," International Journal of Immunopharmacology, vol. 21, no. 3, pp. 149-159, 1999.
[232] L.-Z. Cao and Z.-B. Lin, "Regulatory effect of Ganoderma lucidum polysaccharides on cytotoxic T-lymphocytes induced by dendritic cells in vitro," Acta Pharmacologica Sinica, vol. 24, no. 4, pp. 312-326, 2003.

[233] Z.-B. Lin and H.-N. Zhang, "Anti-tumor and immunoregulatory activities of Ganoderma lucidum and its possible mechanisms," Acta Pharmacologica Sinica, vol. 25, no. 11, pp. 13871395, 2004.

[234] A. Yousofi, S. Daneshmandi, N. Soleimani, K. Bagheri, and M. H. Karimi, "Immunomodulatory effect of Parsley (Petroselinum crispum) essential oil on immune cells: mitogen-activated splenocytes and peritoneal macrophages," Immunopharmacology and Immunotoxicology, vol. 34, no. 2, pp. 303-308, 2012.

[235] F. R. F. Nascimento, E. S. B. Barroqueiro, A. P. S. Azevedo et al., "Macrophage activation induced by Orbignya phalerata Mart," Journal of Ethnopharmacology, vol. 103, no. 1, pp. 53-58, 2006.

[236] G. V. B. Cruz, P. V. S. Pereira, F. J. Patrício et al., "Increase of cellular recruitment, phagocytosis ability and nitric oxide production induced by hydroalcoholic extract from Chenopodium ambrosioides leaves," Journal of Ethnopharmacology, vol. 111, no. 1, pp. 148-154, 2007.

[237] J.-H. Ryul, H. Ahn, J. Y. Kim, and Y.-K. Kim, "Inhibitory activity of plant extracts on nitric oxide synthesis in LPS-activated macrophages," Phytotherapy Research, vol.17, no. 5, pp. 485-489, 2003.

[238] M. Hattori and T. D. Taylor, "The human intestinal microbiome: a new frontier of human biology," DNA Research, vol. 16, no. 1, pp. 1-12, 2009.

[239] D. C. Savage, "Microbial ecology of the gastrointestinal tract," Annual Review of Microbiology, vol. 31, pp. 107-133, 1977.

[240] L. Dethlefsen, M. McFall-Ngai, and D. A. Relman, "An ecological and evolutionary perspective on humang-microbe mutualism and disease," Nature, vol. 449, no. 7164, pp. 811-818, 2007.

[241] I. Sekirov, S. L. Russell, L. C. Antunes, and B. B. Finlay, "Gut microbiota in health and disease," Physiological Reviews, vol. 90, no. 3, pp. 859-904, 2010.

[242] J. I. Gordon and T. R. Klaenhammer, "A rendezvous with our microbes," Proceedings of the National Academy of Sciences of the United States of America, vol. 108, no. 1, pp. 4513-4515, 2011.

[243] B. Khor, A. Gardet, and R. J. Xavier, "Genetics and pathogenesis of inflammatory bowel disease," Nature, vol. 474, no. 7351, pp. 307-317, 2011.

[244] R. E. Ley, P. J. Turnbaugh, S. Klein, and J. I. Gordon, "Microbial ecology: human gut microbes associated with obesity," Nature, vol. 444, pp. 1022-1023, 2006.

[245] S. H. Duncan, A. Belenguer, G. Holtrop, A. M. Johnstone, H. J. Flint, and G. E. Lobley, "Reduced dietary intake of carbohydrates by obese subjects results in decreased concentrations of butyrate and butyrate-producing bacteria in feces," Applied and Environmental Microbiology, vol. 73, no. 4, pp. 1073-1078, 2007.

[246] K. Brown, D. DeCoffe, E. Molcan, and D. L. Gibson, "Dietinduced dysbiosis of the intestinal microbiota and the effects on immunity and disease," Nutrients, vol. 4, no. 8, pp. 1095-1119, 2012.

[247] S. Ghosh, C. Dai, K. Brown et al., "Colonic microbiota alters host susceptibility to infectious colitis by modulating inflammation, redox status, and ion transporter gene expression," American Journal of Physiology-Gastrointestinal and Liver Physiology, vol. 301, no. 1, pp. G39-G49, 2011.

[248] L. A. David, C. F. Maurice, R. N. Carmody et al., "Diet rapidly and reproducibly alters the human gut microbiome," Nature, vol. 505, pp. 559-563, 2013. 
[249] M. T. Bailey, S. E. Dowd, N. M. A. Parry, J. D. Galley, D. B. Schauer, and M. Lyte, "Stressor exposure disrupts commensal microbial populations in the intestines and leads to increased colonization by Citrobacter rodentium," Infection and Immunity, vol. 78, no. 4, pp. 1509-1519, 2010.

[250] A. R. Mackos, T. D. Eubank, N. M. Parry, and M. T. Bailey, "Probiotic Lactobacillus reuteri attenuates the stressorenhanced severity of Citrobacter rodentium infection," Infection and Immunity, vol. 81, no. 9, pp. 3253-3263, 2013.

[251] J. A. Hawrelak, T. Cattley, and S. R. Myers, "Essential oils in the treatment of intestinal dysbiosis: a preliminary in vitro study," Alternative Medicine Review, vol. 14, no. 4, pp. 380-384, 2009.

[252] R. di Pasqua, V. de Feo, F. Villani, and G. Mauriello, "In vitro antimicrobial activity of essential oils from Mediterranean Apiaceae, Verbenaceae and Lamiaceae against foodborne pathogens and spoilage bacteria," Annals of Microbiology, vol. 55, no. 2, pp. 139-143, 2005.

[253] D. Thapa, R. Losa, B. Zweifel, and R. John Wallace, "Sensitivity of pathogenic and commensal bacteria from the human colon to essential oils," Microbiology, vol. 158, no. 11, pp. 2870-2877, 2012.

[254] S. Karmakar, R. Sahay Khare, S. Ojha, K. Kundu, and S. Kundu, "Development of probiotic candidate in combination with essential oils from medicinal plant and their effect on enteric pathogens: a review," Gastroenterology Research and Practice, vol. 2012, Article ID 457150, 6 pages, 2012.

[255] M. Stratford and T. Eklund, "Organic acids and esters," in Food Preservatives, N. J. Russell and G. W. Gould, Eds., pp. 48-84, Kluwer Academic/Plenum Publishers, London, UK, 2003.

[256] G. W. Gould, "Introduction," in Mechanisms of Action of Food Preservation Procedures, G. W. Gould, Ed., pp. 1-42, Elsevier, London, UK, 1989.

[257] R. M. Cava-Roda, A. Taboada-Rodríguez, M. T. ValverdeFranco, and F. Marín-Iniesta, "Antimicrobial activity of vanillin and mixtures with cinnamon and clove essential oils in controlling Listeria monocytogenes and Escherichia coli O157:H7 in milk," Food and Bioprocess Technology, vol. 5, no. 6, pp. 21202131, 2012.

[258] J. Gutierrez, C. Barry-Ryan, and P. Bourke, "The antimicrobial efficacy of plant essential oil combinations and interactions with food ingredients," International Journal of Food Microbiology, vol. 124, no. 1, pp. 91-97, 2008.

[259] M. Hyldgaard, T. Mygind, and R. L. Meyer, "Essential oils in food preservation: mode of action, synergies, and interactions with food matrix components," Frontiers in Microbiology, vol. 3, article 12, 2012.

[260] C. F. Bagamboula, M. Uyttendaele, and J. Debevere, "Inhibitory effect of thyme and basil essential oils, carvacrol, thymol, estragol, linalool and p-cymene towards Shigella sonnei and S. flexneri," Food Microbiology, vol. 21, no. 1, pp. 33-42, 2004.

[261] B. Prakash, R. Shukla, P. Singh, A. Kumar, P. K. Mishra, and N. K. Dubey, "Efficacy of chemically characterized Piper betle L. essential oil against fungal and aflatoxin contamination of some edible commodities and its antioxidant activity," International Journal of Food Microbiology, vol. 142, no. 1-2, pp. 114-119, 2010.

[262] J. Gutierrez, G. Rodriguez, C. Barry-Ryan, and P. Bourke, "Efficacy of plant essential oils against foodborne pathogens and spoilage bacteria associated with ready-to-eat vegetables: antimicrobial and sensory screening," Journal of Food Protection, vol. 71, no. 9, pp. 1846-1854, 2008.
[263] G. R. Beecher, "Overview of dietary flavonoids: nomenclature, occurrence and intake," Journal of Nutrition, vol. 133, no. 10, pp. 3248S-3254S, 2003.

[264] F. Y. Chye and S. N. Hoh, "Antimicrobial activity of flavonoid extracts from Sabah tea (Camellia sinensis) against Escherichia coli and Listeria monocytogenes," Journal of Tropical Food Science, vol. 35, pp. 245-251, 2007.

[265] D. D. Orhan, B. Özçelik, S. Özgen, and F. Ergun, "Antibacterial, antifungal, and antiviral activities of some flavonoids," Microbiological Research, vol. 165, no. 6, pp. 496-504, 2010.

[266] P. Rattanachaikunsopon and P. Phumkhachorn, "Contents and antibacterial activity of flavonoids extracted from leaves of Psidium guajava," Journal of Medicinal Plants Research, vol. 4, no. 5, pp. 393-396, 2010.

[267] B. Ozçelik, D. D. Orhan, S. Ozgen, and F. Ergun, "Antimicrobial activity of flavonoids against extended-spectrum $\beta$-lactamase (ES $\beta \mathrm{L})$-producing Klebsiella pneumoniae," Tropical Journal of Pharmaceutical Research, vol. 7, pp. 1151-1157, 2008.

[268] T. P. Cushnie and A. J. Lamb, "Antimicrobial activity of flavonoids," International Journal of Antimicrobial Agents, vol. 26, no. 5, pp. 343-356, 2005.

[269] S. Ignacimuthu, M. Pavunraj, V. Duraipandiyan, N. Raja, and C. Muthu, "Antibacterial activity of a novel quinone from the leaves of Pergularia daemia (Forsk., a traditional medicinal plant," Asian Journal of Traditional Medicines, vol. 4, pp. 36-40, 2009.

[270] D. N. Singh, N. Verma, S. Raghuwanshi, P. K. Shukla, and D. K. Kulshreshtha, "Antifungal anthraquinones from Saprosma fragrans," Bioorganic and Medicinal Chemistry Letters, vol. 16, no. 17, pp. 4512-4514, 2006.

[271] C. Engels, M. Knödler, Y.-Y. Zhao, R. Carle, M. G. Gänzle, and A. Schieber, "Antimicrobial activity of gallotannins isolated from mango (Mangifera indica L.) kernels," Journal of Agricultural and Food Chemistry, vol. 57, no. 17, pp. 7712-7718, 2009.

[272] A. Basile, S. Sorbo, V. Spadaro et al., "Antimicrobial and antioxidant activities of coumarins from the roots of Ferulago campestris (Apiaceae)," Molecules, vol. 14, no. 3, pp. 939-952, 2009.

[273] J. Ulate-Rodríguez, H. W. Schafer, E. A. Zottola, and P. M. Davidson, "Inhibition of Listeria monocytogenes, Escherichia coli O157:H7, and Micrococcus luteus by linear furanocoumarins in a model food system," Journal of Food Protection, vol. 60, no. 9, pp. 1050-1054, 1997.

[274] K. N. Venugopala, V. Rashmi, and B. Odhav, "Review on natural coumarin lead compounds for their pharmacological activity," BioMed Research International, vol. 2013, Article ID 963248, 14 pages, 2013.

[275] M. Saleem, M. Nazir, M. S. Ali et al., "Antimicrobial natural products: an update on future antibiotic drug candidates," Natural Product Reports, vol. 27, no. 2, pp. 238-254, 2010.

[276] A. Ulubelen, "Cardioactive and antibacterial terpenoids from some Salvia species," Phytochemistry, vol. 64, no. 2, pp. 395-399, 2003.

[277] S. M. Bach, M. A. Fortuna, R. Attarian et al., "Antibacterial and cytotoxic activities of the sesquiterpene lactones cnicin and onopordopicrin," Natural Product Communications, vol. 6, no. 2, pp. 163-166, 2011.

[278] O. Batista, A. Duarte, J. Nascimento, and M. F. Simoes, "Structure and antimicrobial activity of diterpenes from the roots of Plectranthus hereroensis," Journal of Natural Products, vol. 57, no. 6, pp. 858-861, 1994. 
[279] M. C. Mathabe, A. A. Hussein, R. V. Nikolova, A. E. Basson, J. J. M. Meyer, and N. Lall, "Antibacterial activities and cytotoxicity of terpenoids isolated from Spirostachys africana," Journal of Ethnopharmacology, vol. 116, no. 1, pp. 194-197, 2008.

[280] K. D. Hardman and C. F. Ainsworth, "Structure of concanavalin A t $2.4-\AA \AA$ resolution," Biochemistry, vol. 11, no. 26, pp. 49104919, 1972.

[281] P. Petnual, P. Sangvanich, and A. Karnchanatat, "A lectin from the rhizomes of turmeric (Curcuma longa L.) and its antifungal, antibacterial, and $\alpha$-glucosidase inhibitory activities," Food Science and Biotechnology, vol. 19, no. 4, pp. 907-916, 2010.

[282] N. Kheeree, P. Sangvanich, S. Puthong, and A. Karnchanatat, "Antifungal and antiproliferative activities of lectin from the rhizomes of Curcuma amarissima Roscoe," Applied Biochemistry and Biotechnology, vol. 162, no. 3, pp. 912-925, 2010.

[283] W. J. Peumans and E. J. van Damme, "Lectins as plant defense proteins," Plant Physiology, vol. 109, no. 2, pp. 347-352, 1995. 

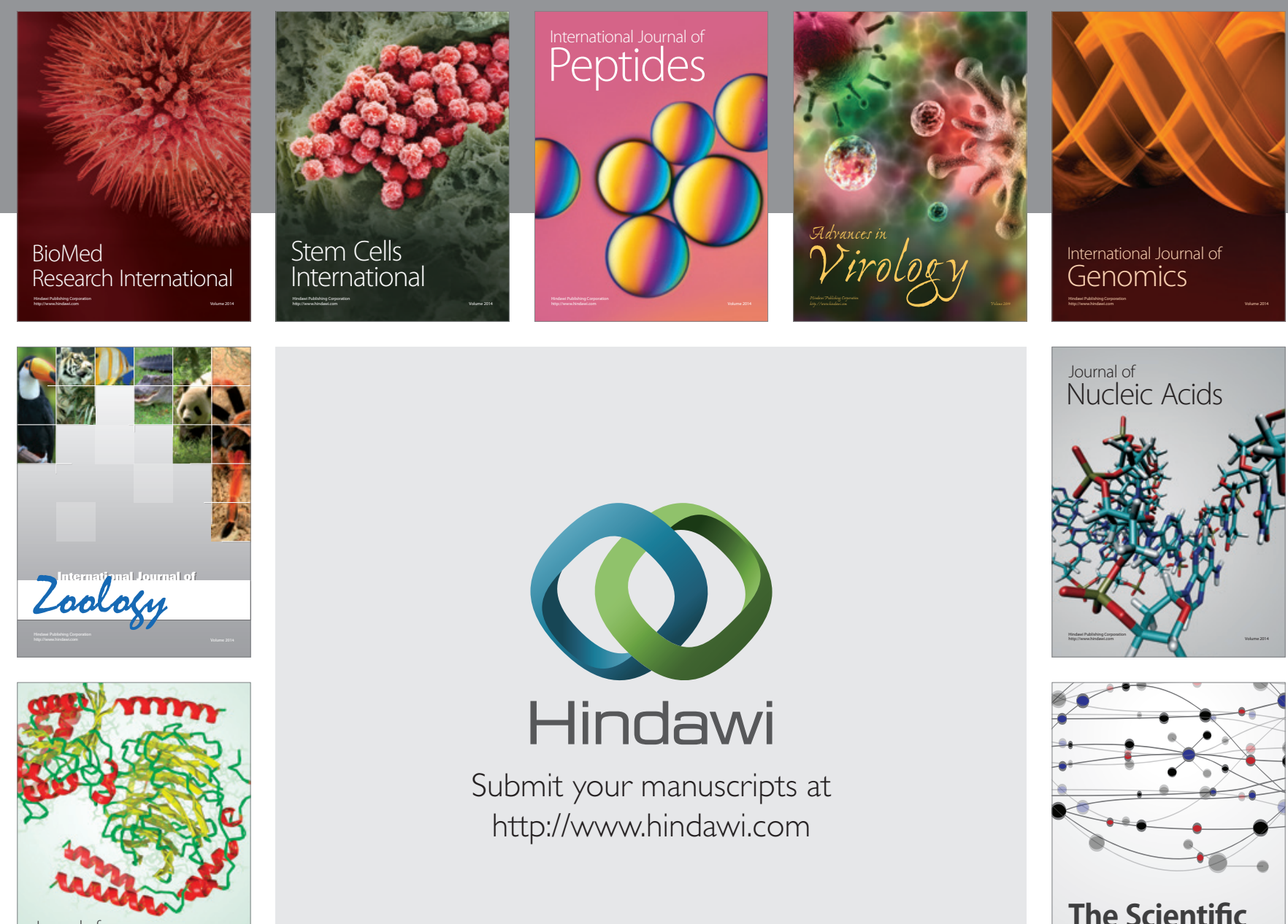

Submit your manuscripts at

http://www.hindawi.com

Journal of
Signal Transduction
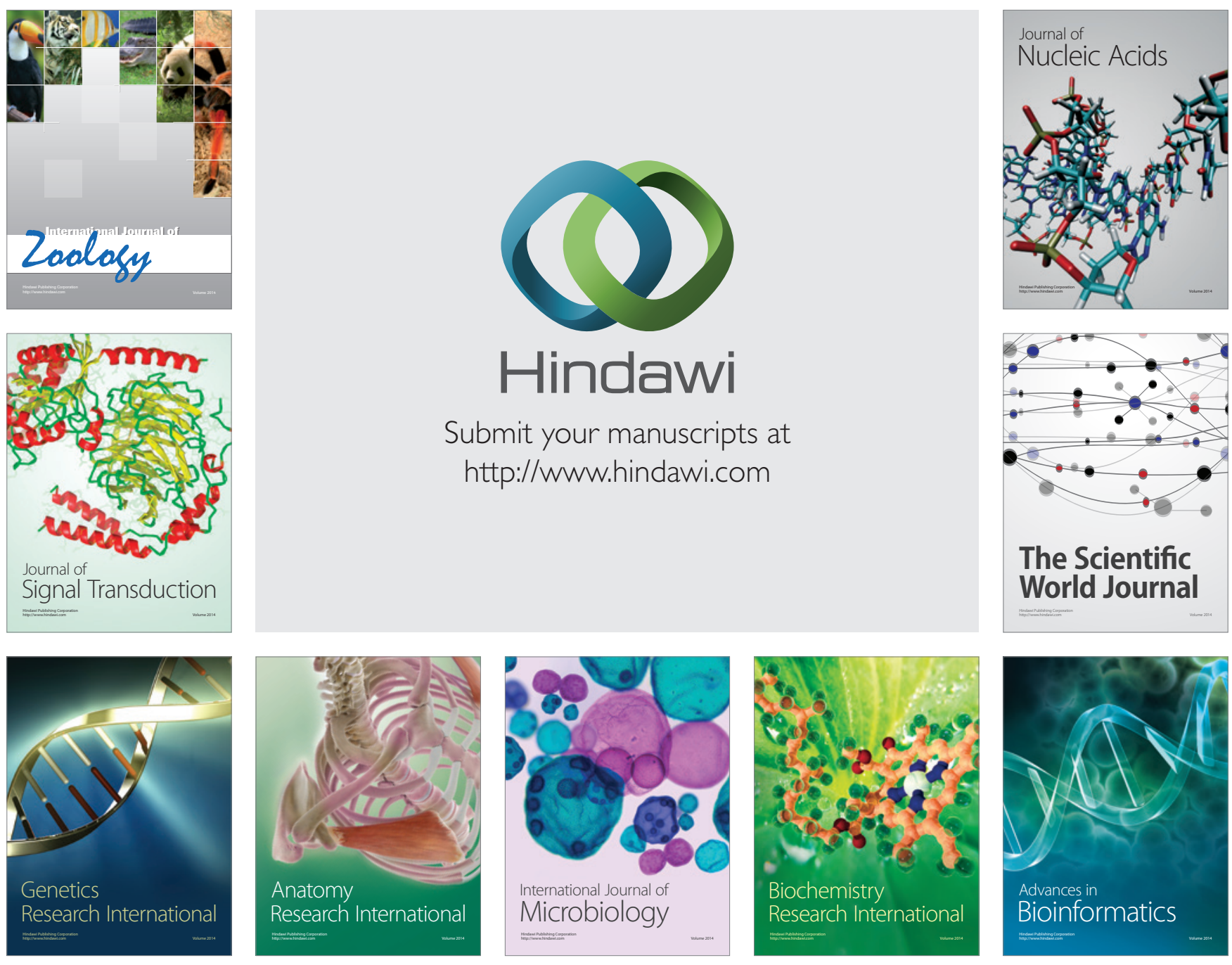

The Scientific World Journal
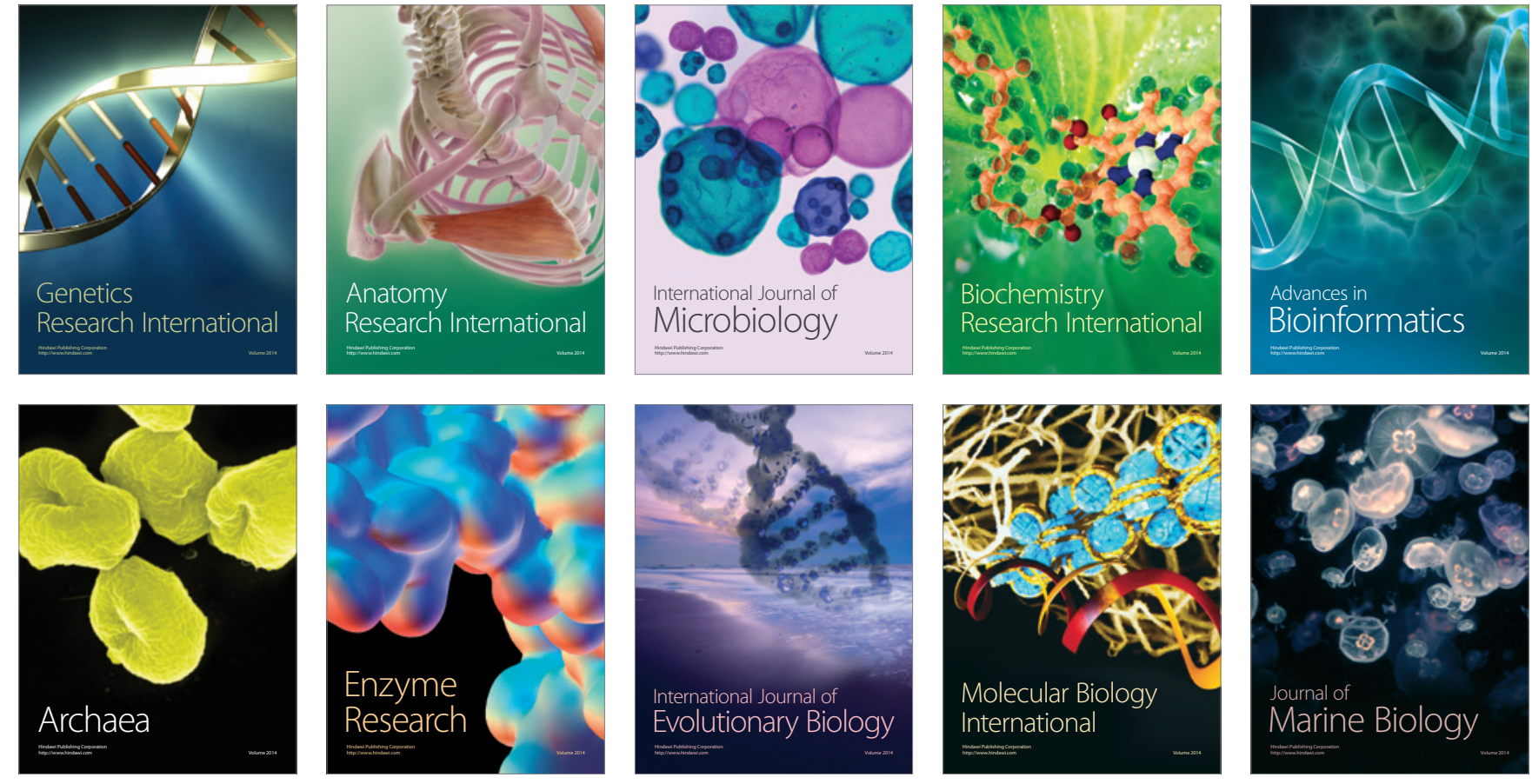